\title{
Valleriola. Tres linajes conversos entre la destrucción de la Judería de Valencia y los procesos de la Inquisición española*
}

\author{
José María Cruselles Gómez** \\ Universitat de València \\ ORCID ID: https://orcid.org/0000-0002-7829-4219
}

\begin{abstract}
Valleriola fue uno de los muchos apellidos que los judíos de Valencia convertidos al cristianismo tras el pogromo de 1391 tomaron de los ciudadanos y magnates que les habían dado protección. A lo largo del siglo xv destacaron tres familias conversas con ese nombre. La primera de ellas, cuyo rastro se remonta a la antigua Judería, contó entre sus descendientes al humanista Joan Lluís Vives. Las otras dos procedían de sendos hermanos Valleriola originarios de Mallorca, que se asentaron en Valencia en torno a 1450. Las tres cosecharon importantes éxitos en el mundo del comercio, las finanzas y la navegación. A partir de las décadas finales de la centuria, los procedimientos represivos puestos en marcha contra los conversos por la nueva Inquisición española pusieron en grave peligro la continuidad de estos linajes, empujando a muchos de sus miembros al exilio o a un destino todavía peor.
\end{abstract}

Palabras Clave: familia; parentesco; onomástica; genealogía; persecución religiosa.

* Este trabajo forma parte del proyecto «Desigualdad económica y movilidad social en la Europa mediterránea (siglos XIII-XVI)», GVPROMETEO2019-072, financiado por la Generalitat Valenciana. Expreso mi agradecimiento a quienes me han facilitado informaciones relevantes para este trabajo: a Rafael Narbona por los datos relativos al ejercicio de cargos municipales en Valencia y Sagunto durante los siglos XIV y XV; a Enrique Cruselles por las referencias documentales acerca de las actividades comerciales de la familia Valleriola y sus socios durante las décadas centrales del siglo xv; y a Bernardo Tomás por los contratos notariales relacionados con la herencia del jurista Jeroni Valleriola a principios del siglo XVII. A lo largo del mismo, téngase en cuenta el uso de las siguientes abreviaturas: ACA, RC $=$ Archivo de la Corona de Aragón, Real Cancillería; ACCV, P = Archivo del Colegio de Corpus Christi, Protocolos; ARV, P = Archivo del Reino de Valencia, Protocolos; c. = circa; Inq. = Archivo Histórico Nacional, Inquisición ; leg. = legajo; $\mathrm{n} .=$ nacimiento; $\mathrm{m} .=$ muerte; s.n. $=\sin$ numerar; s.f. $=\sin$ foliar.

** jose.m.cruselles@uv.es

Copyright: (C) 2021 CSIC. Este es un artículo de acceso abierto distribuido bajo los términos de la licencia de uso y distribución Creative Commons Reconocimiento 4.0 Internacional (CC BY 4.0). 
Valleriola. Three Converted Lineages between the Destruction of Valencia's Jewish Quarter and the Proceedings of the Spanish Inquisition.- Valleriola was one of many surnames that the Jewish people in Valencia that converted into Christianity after the pogrom in 1391 took from the citizens and magnates that had protected them. Throughout the 15th Century three families with that surname stood out. The first one, whose traces date back to the old Jewish Quarter, had the humanist Joan Lluís Vives among its descendants. The other two came from each of the Valleriola brothers from Mallorca, who settled down in Valencia around 1450. The three families reaped major successes in the world of commerce, finances and navigation. From the last decades of the century onwards, the repressing proceedings initiated against the converts by the new Spanish Inquisition jeopardised the continuity of these lineages, pushing many of their members into exile or into an even worse fate.

Keywords: Family; Kinship; Onomastics; Genealogy; Religious persecution.

\section{INTRODUCCIÓN}

El 27 de julio de 1465, en el que sería su último testamento, el ciudadano de Valencia Daniel Valleriola dispuso ser enterrado en el cementerio o fossar del benaventurat Sanct Christòfol, en la fossa o vas que eligieran sus albaceas, con participación en el sepelio de la cofradía de Sant Cristòfol, de la que era miembro. Desde su fundación en 1399, esta asociación había incorporado a muchos de los judíos de la ciudad de Valencia que se convirtieron al cristianismo en los años posteriores al asalto perpetrado en 1391 contra la Judería; después, a lo largo del siglo Xv, acogió también a buena parte de sus descendientes, convirtiéndose en una verdadera seña de identidad para aquellas familias que remontaban sus orígenes hasta la primera comunidad de judeoconversos capitalinos ${ }^{1}$. En las décadas centrales del siglo, Daniel

${ }^{1}$ Los primeros estatutos de la cofradía de Sant Cristòfol fueron aprobados por el rey Martín en Zaragoza el 20 de enero de 1399 y han sido publicados en Colección de documentos inéditos del Archivo General de la Corona de Aragón, vol. 41: Gremios y cofradias de la antigua Corona de Aragón, ed. Francisco Bofarull y Sans, tomo II (Barcelona: L. Benaiges, 1910) págs. 117-128. En los años siguientes el monarca fue ampliando los privilegios de la cofradía hasta sancionar unos estatutos nuevos y más amplios el 20 de agosto de 1407 (ACA, RC 2204, fols. 176v-180), recientemente publicados en Juan Martínez Vinat, Cofradías y oficios. Entre la acción confraternal y la organización corporativa en la Valencia medieval (1238-1516) (Tesis doctoral; Universidad de Valencia, 2018) págs. 2015-2031. 
Valleriola encabezaba una de esas familias y era un reputado miembro de la institución, de la que fue mayoral y clavario en $1462^{2}$. Ejercía el oficio de corredor y en 1457 se incorporó al Consell entre los representantes de los menestrales, pero su comportamiento económico era más propio de un mercader y el lugar que ocupaba en el medio social urbano correspondía antes a la mà mitjana, el grupo que reunía a las clases medias adineradas, que al mundo artesanal. Una posición que consolidaron sus descendientes inmediatos. Hacia mediados de los años cuarenta, Daniel introdujo en los negocios a su hijo Joan, quien sería calificado habitualmente como mercader de Valencia y desarrollaría una exitosa carrera hasta su muerte en $1480^{3}$.

El apellido Valleriola no era nuevo en los ambientes mercantiles y financieros valencianos. Designaba a una importante familia de hombres de negocios que, desde mediados del siglo xIV, estaba fuertemente enraizada en las instituciones políticas y económicas de la ciudad; uno de aquellos linajes patricios sobre los que descansaba el gobierno municipal. Sus orígenes se remontaban al comienzo de esa centuria, a un mercader relativamente modesto llamado Bernat Valleriola cuyo hijo, Arnau Valleriola (m.1367), terminó convertido en uno de los principales banqueros de la ciudad de Valencia y, en palabras de su biógrafo, en un auténtico plutócrata que consiguió elevar a sus vástagos hasta las filas de la nobleza y convertirse él mismo en titular de algunos señoríos ${ }^{4}$. Unos años después, su hijo Joan Valleriola, ciudadano de Valencia, haría carrera en el gobierno municipal. Entre 1382 y 1394 ejerció al menos en cuatro ocasiones el cargo de conseller por la parroquia de Sant Joan del Mercat, fue elegido jurat dels ciutadans en 1418 y al año siguiente se incorporó de nuevo a la nó-

2 ACCV, P 11368. Notario Manuel d'Esparça. 1462, febrero 22.

${ }^{3}$ En 1446, a fin de que su hijo pudiera comerciar y atender otros negocios en su nombre, el corredor Daniel Valleriola otorgó poderes notariales en favor de Joan, al que denominaremos Joan Valleriola II para diferenciarlo de quien pensamos pudo ser su abuelo, el sastre Joan Valleriola I (ACCV, P 25971. Notario Pere Castellar. 1446, julio 7).

4 Juan Vicente García Marsilla, «La tumba de un banquero: el sepulcro de Arnau de Valleriola en el Museo de Bellas Artes de Valencia», en El Mediterráneo y el Arte Español, Actas del XI congreso del CEHA (Valencia: Comité Español de Historia del Arte, 1998) págs. 467-470, y «Arnau de Valeriola», en Real Academia DE LA Historia, Diccionario Biográfico electrónico [DB e: <http://dbe.rah.es/biografias/108182/arnaude-valleriola>; consulta 20 junio 2021]. 
mina del Consell en calidad de jurat vell ${ }^{5}$. De hecho, en vísperas del ataque a la Judería, Joan formó parte de la comisión creada por el rey Juan I para dirimir las disputas surgidas en torno a los nuevos límites establecidos para el gueto, cuyas reducidas dimensiones habían obligado a emprender una problemática ampliación que se vio interrumpida por los acontecimientos de $1391{ }^{6}$. Tras ellos, en el verano de 1392, Joan Valleriola actuaba como «actor y procurador» de los jurados y el Consell 7 ; y pensamos que fue él mismo quien, en el mes de diciembre de ese mismo año, compró al monarca las antiguas carnicerías de los judíos por la substanciosa cantidad de cuatro mil florines ${ }^{8}$. La familia había mantenido tratos comerciales con sus convecinos hebreos desde que Arnau Valleriola, padre de Joan, se asoció en 1353 con el destacado financiero Jafudà Alatzar en el lucrativo negocio de los arrendamientos municipales ${ }^{9}$. En este sentido, resulta razonable pensar que sus descendientes, con el insigne prócer Joan

${ }^{5}$ Con toda la prudencia que exige la homonimia característica de estos linajes patricios, podemos pensar que se trata del mismo Joan Valleriola que fue elegido jurado en 1387 y missatger del Consell en 1390, aunque este último estaba avecindado en la parroquia de Sant Nicolau. La vinculación de familias y personas a parroquias diferentes constituía una estrategia para ampliar la presencia institucional del clan, en consonancia con un sistema que repartía a partes iguales la representación política de la mà mitjana entre dichas parroquias, convertidas en circunscripciones electorales; Rafael NARBONA VIzCaíno, Valencia, municipio medieval. Poder político y luchas ciudadanas, 1239-1418 (Valencia: Ajuntament de València, 1995) págs. 122-123.

${ }^{6}$ José Hinojosa Montalvo, En el nombre de Yahveh: La judería de Valencia en la Edad Media (Valencia: Ajuntament de València, 2007) págs. 426-427. La comisión regia en favor de Joan Valleriola, en ACA, RC, 1847, fol. 32.

7 ACCV, P 1287. Notario Joan d'Aguilar. 1392, junio 28.

${ }^{8}$ La venta, realizada por un agente comercial de Juan I a favor del venerabili Johanni de Valleriola, civi Valentie (ACA, RC, 1906, fols. 109-112), resulta coherente con la inclinación que esta familia demostraba hacia el negocio del abastecimiento cárnico desde los tiempos de aquel primer Bernat Valleriola, que en 1318 se asoció a un carnicero de Gandía para comerciar con ganado (GARCía MARsilla, «La tumba de un banquero», pág. 467), y que se prolongaría durante el siglo Xv con importantes inversiones en el sector; Juan Vicente García Marsilla, «Las Carnicerías Mayores de Valencia al final de la Edad Media: monopolio, inversión y beneficio», en Los carniceros y sus oficios (España-Francia, ss. XIII-XVI), coords. Catherine Verna y Sandrine Victor (Valencia: Universitat de València, 2020) págs. 101-130: 111-118.

9 Jaume Riera I SANZ, «Jafudà Alatzar, jueu de València (segle XIV)», Revista d'Història Medieval 4 (1993) págs. 65-100: 82-93. 
Valleriola a la cabeza, respondieran a las difíciles circunstancias del pogromo de 1391 como tantas otras familias del patriciado urbano: brindando protección y apadrinamiento a las familias judías que, obligadas a renunciar a su fe para salvar la vida, sustituyeron sus propios nombres y apellidos por los de tales padrinos ${ }^{10}$.

De esta manera, de los rescoldos del ataque a la Judería surgió una familia Valleriola "nueva", muy distante en lo que a riqueza e influencia política se refiere de los poderosos patricios cuyo apellido había tomado. Sin embargo, estos Valleriola judeoconversos han atraído la atención de los historiadores porque, precisamente, el mercader Joan Valleriola II (m.1480) fue uno de los bisabuelos del filósofo Joan Lluís Vives ${ }^{11}$, y el corredor Daniel Valleriola I (m.1465), padre de dicho Joan, uno de los ancestros que permiten remontar la genealogía del humanista valenciano hasta los años inmediatamente posteriores a la destrucción del gueto. Ignoramos qué edad tenía Daniel cuando murió, lo que hace difícil saber si pudo haber nacido antes de 1391, pero en tal caso no era sino un niño de corta edad cuando se produjo el pogromo. Volveremos sobre esta cuestión más adelante, porque para darle respuesta necesitamos resolver primero un problema más complejo: la identidad de sus padres.

\section{Cuestión DE NOMBRES: FAMILIAS JUdíAS Y CONVERSAS A FINALES DEL SIGLO XIV}

La práctica habitual de los historiadores para identificar los ancestros judíos de las familias conversas valencianas, ha pasado a menudo por escrutar los contratos notariales llevados a cabo en los últimos años del siglo XIV y primeros del XV. Como consecuencia de la avalancha de conversiones que siguió a la destrucción de la Judería en 1391, cuando

10 Aunque los hechos relacionados con el asalto a la Judería valenciana han sido recogidos por diversos autores, resulta particularmente atractiva la interpretación que, dentro de un contexto político significativamente más amplio, se hace en Rafael Narbona Vizcaíno, «El trienio negro: Valencia, 1389-1391. Turbulencias coetáneas al asalto de la Judería», En la España Medieval 35 (2012) págs. 177-210.

11 Angelina García, Els Vives, una família de jueus valencians (Valencia: Tres i Quatre, 1987) págs. 127 y 248 , nota 18. 
los antiguos judíos actuaban como otorgantes, beneficiarios e incluso simples testigos en dichos contratos, era habitual que junto a sus nuevos nombres cristianos se incluyeran calificativos latinos como conversus o neophitus. Los sucesos recientes habían multiplicado los casos de homonimia y se hacía necesario establecer con exactitud el origen de aquellos nuevos actores documentales. Además, cuando un contrato afectaba a derechos adquiridos o renunciados antes del bautismo, se ponía el antiguo nombre y los apellidos hebreos precedidos del adverbio latino olim (en otro tiempo, anteriormente), a fin de aclarar mejor la identidad. De esta forma, expurgando los registros de notarios como Bartomeu de la Mata o Miquel Arbúcies, los historiadores han podido establecer algunas correspondencias entre los nombres de familia utilizados antes y después de la conversión ${ }^{12}$.

En su día, este procedimiento permitió a Angelina García identificar al ancestro judío de Joan Lluís Vives por línea paterna, el mercader Jacob Abenfaçam, y también al padre de este, Abrafim Abenfaçam, convertidos respectivamente en Gabriel y Francesc Vives ${ }^{13}$. Sin embargo, la autora no obtuvo resultados igualmente satisfactorios con otros antepasados del filósofo, como es el caso de los Valleriola, porque un procedimiento onomástico de estas características exige algo más que localizar un contrato donde se registren los dos nombres de una misma persona, el anterior judío y el posterior cristiano. Sin restar importancia a la parte que ha jugado el azar tanto en la conservación de estos documentos como en su localización por parte de los historiadores, cuya paciente búsqueda no tiene por qué rendir necesariamente los frutos

${ }^{12}$ Los registros notariales de Bartomeu de la Mata se encuentran repartidos entre el ARV (siete volúmenes datados entre 1386 y 1401) y el ACCV (siete volúmenes entre 1398 y 1419). En este último archivo se custodian los registros de Miquel Arbúcies (doce volúmenes entre 1385 y 1419). Aunque diversos historiadores valencianos han recurrido a esta documentación con el propósito indicado, el único trabajo de identificación sistemático llevado a cabo hasta el momento, desafortunadamente inédito, se lo debemos a José Luis Luz Company, Evolución y estrategias de integración de las familias judeoconversas valencianas en el tránsito al siglo XV (Tesis de licenciatura; Universidad de Valencia, 1993). Una breve síntesis de aquel trabajo fue publicada en José Luis Luz CompaÑ, «Familias judías-familias conversas. Aproximación a los neófitos valencianos del siglo XIV», Espacio, Tiempo y Forma. Serie III. Historia Medieval 6 (1993) págs. 409-424.

13 García, Els Vives, págs. 90, 122-124 y 244-247. 
apetecidos, cabe señalar que las circunstancias en que se produjeron aquellas conversiones añaden no pocas dificultades a nuestra labor.

Muchos judíos que en 1391 aceptaron abrazar el cristianismo para salvar sus vidas y haciendas, fueron apadrinados por los mismos cristianos viejos que les habían dado protección en sus propias casas durante el ataque ${ }^{14}$. Personas con las que, sin duda, mantenían relaciones previas de naturaleza comercial, aunque no cabe descartar otras de amistad y mutuo aprecio. Buena parte de aquellos padrinos improvisados eran miembros de destacadas familias de la oligarquía ciudadana, lo que animó sin duda a muchos judíos amenazados, no necesariamente miembros de una misma familia, a buscar su auxilio y adoptar su nombre. En consecuencia, muchos judíos procedentes de familias distintas terminaron reunidos bajo el mismo apellido cristiano tras la conversión, sin que existiera entre ellos ningún parentesco de sangre previo. A esto cabe añadir que no todos los judíos que sí compartían apellido antes de ser bautizados, adoptaron después el mismo apellido cristiano, quizás porque encontraron protectores distintos o por otros motivos más difíciles de determinar. La conversión generó, por tanto, vínculos consanguíneos espurios y rompió otros auténticos. En consecuencia, no basta con localizar el apellido que buscamos, también es necesario determinar las distintas familias judías que lo adoptaron y a cuáles de ellas concierne nuestra búsqueda; y esto hace que el procedimiento resulte mucho más laborioso e imprevisible.

José Luis Luz Company dio cuenta en su trabajo de diez individuos varones que, siendo calificados inequívocamente como conversos, adoptaron entre 1391 y 1403 el apellido Valleriola. Podemos pensar que no se trata de un número muy elevado, pero esas diez personas procedían al menos de cuatro familias judías distintas, cuyos apellidos habían sido

${ }^{14}$ Es bien conocido el caso del médico judío Umer Tahuell, que viéndose obligado a bautizarse cuando los asaltantes amenazaron con quemar la casa del noble Pere d'Artés, en la que se había refugiado junto con su familia, tomó el nombre de su protector y padrino bautismal, convirtiéndose en mestre Pere d'Artés, médico; José Hinojosa Montalvo, «Los conversos de judío valencianos en el siglo Xv entre el desarraigo y la asimilación», en La Península Ibérica en la era de los descubrimientos (1391-1492). Actas III Jornadas Hispano-Portuguesas de Historia Medieval, eds. Manuel GonzÁLeZ

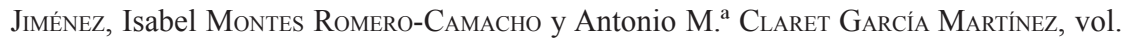
1 (Sevilla: Junta de Andalucía, 1997) págs. 69-98: 72. 
Arles, Tetnira, Morcat y Camis ${ }^{15}$. Además, cuatro de estos nuevos Valleriola tomaron el nombre propio de Joan -un hecho que inevitablemente remite al ciudadano Joan Valleriola, protagonista en aquellos años de una destacada carrera política- y de esos cuatro, tres al menos procedían de familias judías diferentes. No se trata de nada extraordinario. El apellido Moncada, el más repetido entre los conversos de aquella primera época (16 individuos), fue adoptado por los miembros de seis familias judías distintas ${ }^{16}$; y el de Vilanova, también frecuente (13 individuos), reunía al menos cinco ${ }^{17}$. No podemos contar, sin embargo, con que ambas magnitudes -la frecuencia de un apellido cristiano y el número de familias judías que lo adoptaron- mantengan una relación proporcional. El de Montagut fue utilizado solamente en cuatro ocasiones, pero remite al menos a tres familias judías ${ }^{18}$; y el de March, tan significativo también para los biógrafos de Vives, aparece en otras cuatro ocasiones y en cada una de ellas corresponde a un apellido judío diferente ${ }^{19}$. Por el contrario, el de Artés, que fue adoptado al menos por diez personas, solamente aparece asociado a dos apellidos hebreos ${ }^{20}$; y aunque son más raros, hay casos en que un apellido cristiano corresponde a una única familia hebrea, como ocurre con el de Mas, que aparece vinculado solamente a conversos llamados antes Abnayub ${ }^{21}$.

15 Luz Company, Evolución y estrategias, pág. 208. Utilizamos aquí los nombres hebreos en la forma que se recoge en el «Índice de personas» incluido en HinoJosa Montalvo, En el nombre de Yahveh, págs. 617-639.

16 Según la mencionada relación de LuZ COMPANY, Evolución y estrategias, págs. 196-197: Abdolaziz, Bonjuha, Lectoix, Mohep, Sibilí y Tori. Este hecho también ha sido señalado en Hinojosa Montalvo, «Los conversos de judío valencianos», pág. 76.

17 Agol, Alfateix, Leví, Vinag, Vives (Luz, Evolución y estrategias, págs. 209-210).

18 Carruc, Mirabell y Tahuell (Luz, Evolución y estrategias, pág. 196).

19 Tres de ellos (Alabu, Bondia, Covo) fueron identificados por Luz (Evolución y estrategias, pág. 193), y el cuarto (Xaprut) por GARCía (Els Vives, pág. 131). Esta autora afirma que es precisamente este último el que corresponde a los ancestros judíos del filósofo, aunque no aporta otra evidencia que el hecho de que dos hermanos Xaprut, Isaac y David, tomaron respectivamente los nombres de Gabriel y Tomás March.

20 Tahuell y Mair. Otro tanto ocurre con el apellido Maçana, que aparece asociado tan solo a dos apellidos judíos: Abenmarueç y Albufadal; Luz CoMPANY, Evolución y estrategias, págs. 185-186 y 193.

${ }^{21}$ Luz Company, Evolución y estrategias, págs. 186-187. 
Pero no terminan aquí los problemas. Como hemos visto, también era corriente que los miembros de una misma familia judía tomaran apellidos cristianos distintos. Los mencionados Xaprut, asociados a la familia conversa March, adoptaron al menos otros cuatro apellidos cristianos: Morant, Pardo, Roís y Soldà 22 ; y, hasta donde sabemos, aunque los Abnayub utilizaron de manera exclusiva el apellido Mas, también tomaron otros como Pardo, Tolsà y València, compartiendo el primero de ellos con alguna otra familia judía, como los Xaprut ${ }^{23}$.

Con la información de la que disponemos hasta el momento, podemos hacer una relación de los conversos Valleriola identificados entre 1391 y $1403^{24}$ :

1. El rabino Fahim d'Arles [Joan Valleriola], arrendador de impuestos y prestamista ${ }^{25}$.

2. La familia de los sederos Tetnira, integrada por Salomó Tetnira [Bernat Valleriola] ${ }^{26}$ y sus tres hijos: Jonàs [Joan Valleriola] ${ }^{27}$, Samuel [Llorens Valleriola] ${ }^{28}$ y un tercero [Simó Valleriola] cuyo nombre judío desconocemos.

22 Luz Company, Evolución y estrategias, pág. 218.

23 Luz Company, Evolución y estrategias, págs.198 y 207-208.

${ }^{24}$ Cuando no se indica otra cosa, la información procede del mencionado trabajo de José Luis Luz.

${ }^{25}$ En 1377 tenía arrendada la sisa del vino; Hinojosa Montalvo, En el nombre de Yahveh, pág. 236. En vísperas del ataque contra la Judería saldaba un préstamo con prenda que había hecho años antes a la noble Isabel Cornell (ARV, P 2496. Notario Bartomeu de la Mata. 1389, agosto 17). Tras la conversión aparece en un documento de 1391 reclamando la devolución de un préstamo; García, Els Vives, pág. 255, nota 34. La última noticia suya que tenemos es un arbitraje acordado el 10 de enero de 1392, al que nos referiremos más adelante ( $c f$. infra nota 39).

${ }^{26}$ En 1402, Bernat Valleriola poseía dos casas en la parroquia de Sant Tomàs; José Hinojosa Montalvo, «Los Muncada, conversos valencianos, 1391-1491», eHumanista/ Conversos 6 (2018) págs. 363-402: 371. Tras su muerte y la de su esposa Clara, uno de dichos inmuebles pasó a ser propiedad pro indiviso de sus tres hijos (ACCV, P 980. Notario Miquel Arbúcies. 1407, junio 17).

${ }^{27}$ Sabemos que Jonàs Tetnira era hijo de Salomó por un contrato notarial anterior a la conversión (ARV, P 4296. Notario Bartomeu de la Mata. 1389, agosto 26).

${ }^{28} \mathrm{Su}$ nombre judío lo trae GarCía, Els Vives, pág. 42; si bien la referencia archivística que aporta la autora está incompleta, como ocurre demasiado a menudo en su trabajo. 
3. El sastre Mossé Morcat [Miquel Valleriola] ${ }^{29}$.

4. Mossé Camis [Joan Valleriola] ${ }^{30}$.

5. Tres individuos de nombre judío desconocido, uno de ellos sastre [Joan Valleriola], otro zapatero [Lluís Valleriola] y el último sedero [Jaume Valleriola] ${ }^{31}$.

Dadas las limitaciones propias de la información que utilizamos, y mientras no podamos modificar o completar esta lista a partir de otros documentos, solo algunos detalles particulares pueden permitirnos hacer frente al problema de la homonimia. El oficio es una de esas peculiaridades; otra las relaciones establecidas con terceras personas, como parientes, socios comerciales, vecinos, etc. En este punto, la reconstrucción de los parentescos judíos anteriores a la conversión aporta informaciones decisivas, como ocurre en el caso de los Tetnira.

Sabemos que, en el momento de la conversión, la familia Tetnira se dividió al menos en tres ramas con apellidos cristianos diferentes. Estaban primero los sederos Valleriola, a los que ya nos hemos referido; en segundo lugar los que tomaron el apellido Durà, entre quienes estaban Abrafim Tetnira $^{32}$ [Joan Durà] y Samuel Tetnira [Berenguer Durà]; y por último los sastres Esplugues, con Mossé Tetnira [Francesc d'Esplugues] y otro cuyo nombre judío desconocemos [Gabriel

${ }^{29}$ En un contrato en el que actuó como testigo en 1389, antes de su conversión, se le califica como junior, de manera que por aquella fecha debía haber un judío homónimo de mayor edad, quizás pariente suyo (ARV, P 4296. Notario Bartomeu de la Mata. 1389, agosto 24).

30 Para nosotros, el más desconocido de todos ellos. Luz Company (Evolución y estrategias, pág. 208) se limita a dar cuenta de su presencia en la documentación notarial entre 1397 y 1400; sabe que era vecino de Valencia, pero no su profesión. Otro Camis, de nombre Salomó, había adoptado sin embargo el nombre cristiano de Salvador Andreu y ejercía el oficio de sastre; Luz Company, Evolución y estrategias, pág. 178.

31 Este último no está incluido en la relación de Luz Company y la única noticia que hasta ahora tenemos de él está en el contrato como sirviente doméstica de la hija de otro converso. En realidad, el documento no afirma que este Jaume sea converso, pero el contexto en el que se sitúa permite suponerlo (ARV, P 1446. Notario Bartomeu de la Mata. 1401, marzo 11).

32 Prestamista particularmente activo entre la clientela mudéjar, que en 1386 había sido clavario de la aljama; Hinojosa Montalvo, En el nombre de Yahveh, pág. 479. 
d'Esplugues] ${ }^{33}$. Este último acordó su matrimonio en 1400 con Caterina, hija conversa del difunto judío Abraham Gabbay, cuyo tutor y curador era otro converso, Joan Valleriola. La relación establecida entre el apellido Esplugues y la antigua familia judía Tetnira permite pensar que este acuerdo matrimonial se estaba llevando a cabo entre dos ramas de esta última, y que el tutor de Caterina era en realidad el sedero Joan Valleriola, antes llamado Jonàs Tetnira ${ }^{34}$. Asimismo, si reparamos en los vecinos que Bernat Valleriola [Salomó Tetnira] y su esposa Clara tenían en su casa de la parroquia de Sant Tomàs, encontraremos a un Joan Durà cuyo nombre judío era Abrafim Tetnira, lo que permite pensar que ambas casas pudieron constituir en tiempos anteriores un único inmueble que resultó dividido en un reparto sucesorio, como de hecho la casa de los Valleriola estaba en 1407 repartida entre los tres hermanos ${ }^{35}$.

No eran los únicos vínculos que conservaban ambas familias. Llorens Valleriola [Samuel Tetnira], hijo de Bernat Valleriola [Salomó Tetnira], estaba casado con una hija de Berenguer Durà [Samuel Tetnira ${ }^{36}$. Suegro y yerno, aunque ahora tenían apellidos cristianos diferentes, habían sido homónimos cuando eran judíos. Por un documento fechado apenas diez días antes del pogromo, sabemos que en la Judería vivían dos hermanos llamados precisamente Samuel y Salomó Tetnira ${ }^{37}$, que sin demasiado riesgo a equivocarnos podemos identificar con Berenguer Durà y Bernat Valleriola. De esta manera, podemos concluir que el enlace matrimonial entre ambas familias fue bastante más endogámico de lo que sugieren sus nuevos apellidos cristianos, pues los esposos eran primos hermanos en realidad (fig. 1).

${ }^{33}$ Luz Company, Evolución y estrategias, pág. 188.

34 ACCV, P 21905. Notario Bartomeu de la Mata. 1400, enero 24.

35 ACCV, P 980. Notario Miquel Arbúcies. 1407, junio 17.

36 ACCV, P 21905. Notario Bartomeu de la Mata. 1400, abril 21.

37 Según el testamento otorgado el día 28 de junio de 1391 por una hermana de ambos, Jamila, viuda de Maimó Çumayeg, que les dejaba las habituales ropas de luto para que las vistieran durante el año siguiente a su defunción; Hinojosa Montalvo, En el nombre de Yahveh, págs. 330-331. El documento completo ha sido incluido en el apéndice documental anexo a esta obra en soporte digital, págs. 135-138. 


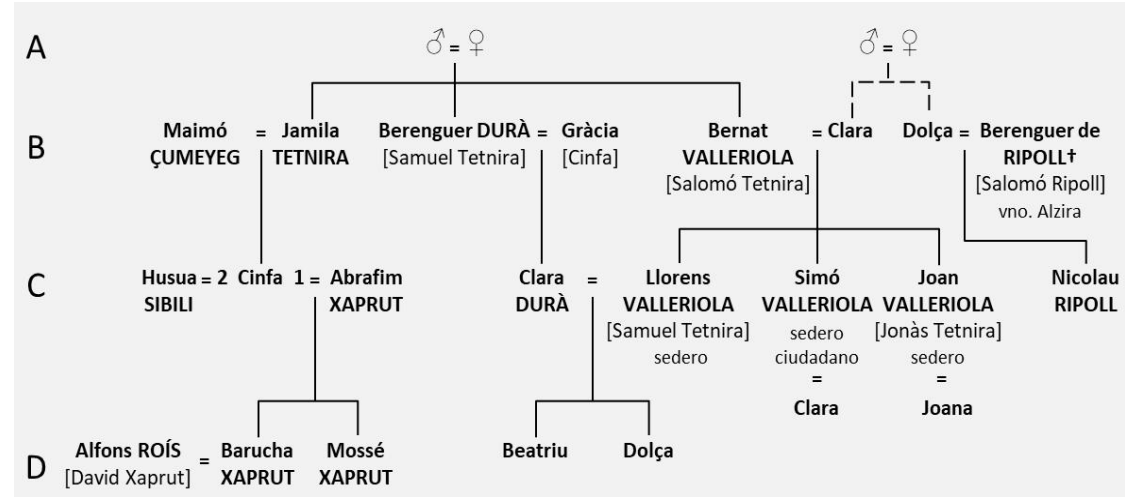

Fig. 1: La familia Tetnira-Valleriola-Durà.

Sin embargo, hay ocasiones en que la identificación de una determinada persona resulta imposible, sencillamente porque los documentos no aportan los detalles que son imprescindibles para confirmarla o, cuanto menos, aventurarla. En estos casos es importante evitar las atribuciones gratuitas de identidad. Así, conservamos documentos de este periodo que se refieren a uno o varios Joan Valleriola que, a día de hoy, no podemos vincular con ninguno de los cuatro incluidos en la relación anterior; y el caso más relevante es sin duda el de ese Joan Valleriola que, entre mayo de 1399 y mayo de 1400, ejerció como mayoral y clavario de la cofradía de Sant Cristòfol. Jaume Castillo afirma que se trata del antiguo rabino Fahim d'Arles, pero su elección no está suficientemente justificada ${ }^{38}$. De hecho, sabemos muy poco del rabino en cuestión y nada con posterioridad al conflicto que mantuvo con un carnicero converso en enero de $1392^{39}$. Por el contrario, los

38 Jaime CASTILlo SAINZ, «De solidaritats jueves a confraries de conversos: entre la fossilització i la integració d'una minoría religiosa», Revista d'Història Medieval 4 (1993) págs. 183-206. Señala el autor que Joan Valleriola recibía en 1392 el calificativo de magister, lo que permitiría reconocer a quienes ya habían ocupado un lugar preeminente en la anterior comunidad judaica; pero en ningún caso se atribuye dicho tratamiento de magister siete años más tarde al mayoral de la mencionada cofradía, lo que a nuestro entender no acredita precisamente la identificación entre ambas personas.

39 El carnicero Ferran Martínez [Samuel Mitjança] de una parte, y de otra el citado magister Joan Valleriola [Fahim d'Arles], el sastre Joan Gençor [Samuel Azaro] y el mercader Gabriel Despuig [Jacob Aliceni], aceptaron someter sus diferencias al arbi- 
otros tres Joan Valleriola incluidos en nuestra relación comparecen de manera efectiva en contratos notariales posteriores a esa fecha, particularmente durante el bienio 1399-1400.

Ni siquiera en la documentación del año 1392 resulta evidente la identificación entre el rabino Fahim d'Arles y cualquier otro Joan Valleriola cuyo nombre no aparezca asociado a ningún rasgo significativo a ese respecto. El 18 de julio, apenas cumplido el primer aniversario del asalto, varias decenas de conversos (vicini Valencie neofiti) se reunieron para designar procuradores que negociaran con el rey Juan I el pago de las deudas de la aljama. El grupo -cuyas profesiones y antiguos nombres judíos no se hicieron constar- lo encabezaba el magister Pere d'Artés, identificado con el médico Umer Tahuell, y entre sus integrantes encontramos no uno, sino dos Joan Valleriola solamente diferenciados por la edad, pues se los calificaba respectivamente como minor y maior dierum. Podemos aventurar, dado que la lista incluía a Berenguer Durà y a dos de sus sobrinos, los hermanos Simó y Llorenç Valleriola, que uno de esos dos Joan Valleriola era el tercer hermano, es decir, el sedero Jonàs Tetnira ${ }^{40}$. ¿El rabino Fahim d'Arles era el otro? ¿Cuál de ellos? Podemos pensar que fuera el considerado de mayor edad, pero si su posición en la comunidad judía había sido tan preeminente, resulta extraño que no se le otorgara el título de magister, como a Pere d'Artés, o que no aparezca en una posición más destacada de una lista en la que ocupa el lugar $45^{\circ}$. En realidad, no tenemos el más leve indicio que sitúe al rabino Fahim d'Arles entre los firmantes, ni se ha encontrado rastro alguno de su presencia en la documentación tras el mencionado conflicto de enero de 1392, ni nada que permita suponer que alguno de los Valleriola identificados en años posteriores pudiera haber sido descendiente suyo.

traje del notario Berenguer Andreu y de un carnicero llamado Francesc, a fin de resolver de manera amistosa el pleito incoado ante la corte civil de Valencia por el pago de ciertos laboribus et expensis (ARV, P 1444. Notario Bartomeu de la Mata. 1392, enero 10).

40 ACCV, P 1287. Notario Joan Aguilar. 1392, julio 18. Hemos concluido que el Llorens Ullerola que ocupaba el puesto $21^{\circ}$ en la lista de firmantes era en realidad Llorens Valleriola, y que un error del notario hizo desaparecer dos letras de su apellido, transformándolo en otro que hasta el momento no hemos podido localizar en ninguna parte, ni entre conversos ni entre cristianos viejos. 
Es comprensible que, entre el puñado de conversos que adoptó el nombre de Joan Valleriola, haya sido Fahim d'Arles el que más poderosamente ha llamado la atención de los historiadores, a causa sin duda de los sugestivos títulos de rabi y magister que se le atribuyen en los documentos de la época. Este ha sido, en nuestra opinión, el argumento que mayor peso ha tenido a la hora de convertirlo en uno de los ancestros judíos del filósofo Joan Lluís Vives, pues no contamos hasta el momento con ninguna información documental que permita suponer la existencia de parentesco alguno entre ambos. Ni siquiera, como hemos visto, para afirmar que ambos podrían descender de un mismo linaje hebreo ${ }^{41}$.

¿Existe algún indicio, más allá de la mera coincidencia onomástica, que permita relacionar con la estirpe de Vives a alguno de los judíos que adoptaron el apellido Valleriola tras su conversión al cristianismo a finales del siglo XIV? La respuesta es afirmativa, pero ni mucho menos concluyente.

\section{La familia Valleriola y el linaje del humanista JoAn Lluís VIVES}

Las conversiones masivas de judíos que siguieron al pogromo de 1391 actuaron como una auténtica coctelera genealógica: una familia judía pudo dividirse en varias familias conversas y los miembros de diferentes familias judías adoptar el mismo apellido cristiano, pasando a constituir, a ojos de un observador poco avisado, un único linaje converso. Por lo que respecta al objeto del presente estudio, estamos lejos de saber cuántos linajes Valleriola distintos pudieron existir entre los conversos valencianos a lo largo del siglo xv, pero entre los que han dejado mayor rastro documental podemos identificar al menos tres ${ }^{42}$.

${ }^{41}$ El argumento que utiliza Angelina García es meramente asertivo: «Els Valleriola provenien del rabí juheu Fahim Darlé». La autora identifica a este con un "recaudador de sisas" activo antes de la conversión, pero lo convierte en el ancestro de la familia conversa Valleriola-Vives sin más prueba que la coincidencia de su apellido; GARCíA, Els Vives, pág. 134.

42 De la misma manera, y por lo que sabemos hasta ahora, no existió un único linaje Vives, sino al menos dos: el de los mercaderes Gabriel Vives [Jacob Abenfaçam] y su hijo Miquel Vives, que contaba entre sus descendientes al humanista Joan Lluís Vives, 
Entre los documentos notariales recopilados por Angelina García en su notable biografía familiar de Joan Lluís Vives, hay uno que no llamó mucho la atención de la autora, aunque constituye el único indicio que tenemos para encontrar, entre todos los habitantes de la antigua Judería, el ancestro del linaje Valleriola. El día 7 de febrero de 1412, un Joan Valleriola identificado como converso y sastre, nombró procurador a su hijo Daniel Valleriola ${ }^{43}$. Según la autora, "otro" descendiente del "primer" Joan Valleriola fue un mercader converso homónimo, activo a mediados del siglo XV, suegro de Lluís Vives II, abuelo paterno del filósofo. Cabe convenir que A. García tiene razón en lo fundamental, que todos ellos eran antepasados del humanista, pero cuando pretende identificarlos con mayor detalle sus argumentos se enredan en la homoni$\mathrm{mia}^{44}$. En este momento conocemos bien, a través de los registros notariales $\mathrm{y}$, sobre todo, de la abundante documentación inquisitorial, el devenir genealógico de esta familia Valleriola-Vives entre mediados del siglo XV y principios del XVI, lo que nos permite arrojar algo más de luz sobre la cuestión de sus orígenes.

y el de los corredores Lluís Vives I y su hijo Pau Vives (ACCV, P 11562. Notario Manuel d'Esparça. 1453, mayo 8). Ambas familias estaban emparentadas a finales del siglo $\mathrm{XV}$ por el matrimonio entre Castellana, hija del mencionado Pau Vives, y Salvador, descendiente de los Abenfaçam. Salvador y Castellana Vives fueron los padres de Miquel Vives, el presunto criptorrabino quemado por la Inquisición a comienzos del siglo XVI, que era primo hermano del mercader Lluís Vives III, padre del filósofo; GARCíA, Els Vives, págs. 91 y 127.

43 García, Els Vives, págs. 134 y 255-256, nota 37. Desafortunadamente no podemos contrastar esta información porque la autora aportó una referencia documental errónea que no se corresponde con el antiguo sistema de clasificación del fondo de registros notariales del Colegio del Patriarca (que asignaba el mismo número a todos los volúmenes de un mismo notario), ni tampoco con el actual número currens.

44 Aunque hace referencia al testamento de Joan Valleriola II, suegro de Lluís Vives II, la autora no indica fecha ni referencia archivística alguna, lo que puede hacer pensar al lector que se trata de un documento cronológicamente anterior a 1474, año en que fue redactado (ACCV. Protocolos, 11378. Notario Manuel d'Esparça. 1474, abril 13). Parece poco probable, en consecuencia, que el heredero de este Joan Valleriola II (m.1480), llamado Daniel Valleriola, fuera el mismo Daniel Valleriola que en 1429 hacía negocios con ciertos mercaderes italianos. García confundió al antiguo rabino Fahim d'Arles [Joan Valleriola] con el sastre Joan Valleriola I, y al hijo de dicho sastre, Daniel Valleriola I (m.1465), con su bisnieto Daniel Valleriola III (m.1484). A todos ellos nos referiremos a continuación con más detalle. 
El nombre de Daniel Valleriola aparece a menudo en la documentación de la segunda mitad del siglo xv, y de manera acertada ha sido asociado al linaje de Joan Lluís Vives. Sin embargo, es importante aclarar que una presencia tan extensa tiene mucho que ver con el hecho de que coexistieran tres personas homónimas, todas ellas dedicadas al comercio, aunque no todas se contaban entre los antepasados del humanista ${ }^{45}$.

Comencemos por el principio. El documento exhumado por Angelina García, que ella data en 1412, contradice su propia afirmación de que el rabino Fahim d'Arles fue el ancestro judío de los Valleriola conversos. También excluye a la familia de los sederos Tetnira, mejor conocida, para dirigir nuestra atención hacia un sastre cuyo nombre hebreo ignoramos ${ }^{46}$. Este Joan Valleriola I, casado con cierta Dolça de cuyos orígenes familiares tampoco sabemos nada, tuvo al menos dos hijos: Daniel Valleriola y Gràcia ${ }^{47}$. Este Daniel, que en 1412 contaba al menos veinte años si pudo constituirse como representante legal de su padre, debió nacer en 1392 o en los años previos, es decir, en torno al momento en que tuvo lugar el ataque contra la Judería. En cuanto a Gràcia, es probable que cuando se estaba negociando su matrimonio en 1416 tuviera como mucho veinte años, lo que situaría su nacimiento en los últimos años del siglo XIV, cuando la familia ya se había convertido al cristianismo. Si consideramos que el Daniel Valleriola I que otorgó su último testamento en el verano de 1465, pocos días antes de su muerte, pudo haber alcanzado la edad relativamente avanzada de 75 años (pues tenía en aquel momento un hijo adulto y varios nietos casados), podemos

45 Utilizamos los numerales romanos como procedimiento convencional para facilitar al lector la identificación de las personas homónimas, primando antes el orden cronológico, es decir, la edad de los individuos, que el vínculo paterno-filial.

46 José Luis Luz detecta su presencia en la documentación notarial a partir de 1397, aunque el primer contrato al que hace referencia explícita es, en 1399, la liquidación de cuentas de una compañía comercial previamente acordada entre dos sastres, Joan Valleriola y Francesc Castellar, y un mercader, Jaume de Vilaragut; Luz Company, Evolución $y$ estrategias, pág. 208. Ese mismo año, el sastre Joan Valleriola negociaba el pago de otra deuda de 40 libras que un monje franciscano llamado Guillem Gralla había contraído con él (ARV, P 1445. Notario Bartomeu de la Mata. 1399, junio 26 y noviembre 13).

${ }^{47}$ En 1416 el sastre Valleriola y su esposa Dolça negociaban el matrimonio de su hija Gràcia con el mercader converso Bonanat de Muncada, un asunto que había acarreado algunos conflictos entre ambas familias; Hinojosa Montalvo, «Los Muncada», pág. 366. 
aventurar que se trataba del mismo Daniel Valleriola nacido en torno a 1391, cuyo padre era el sastre Joan Valleriola I. Esta suposición es, sin duda, bastante menos sugestiva que la tocante al rabino Fahim d'Arles, pero tiene la virtud de estar fundamentada en indicios documentales, que es más de lo que hasta ahora teníamos.

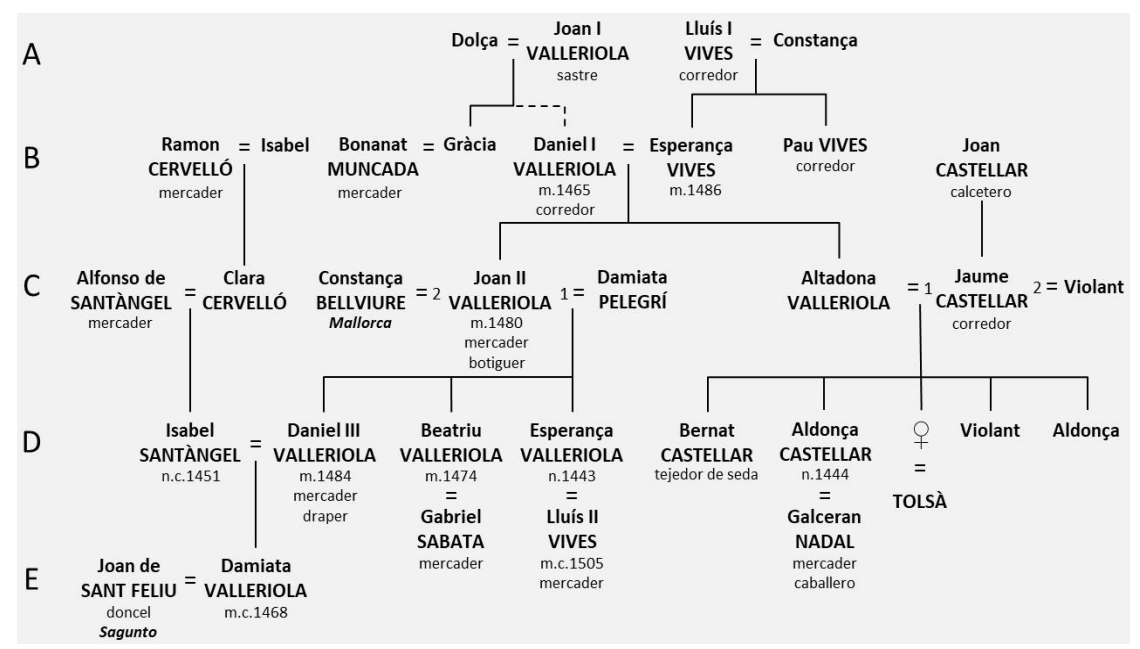

Fig. 2: La familia Valleriola-Vives

A partir de aquí pisamos terreno más firme (fig. 2). El corredor Daniel Valleriola I (c.1391-1465) contrajo matrimonio con Esperança Vives, hija de Lluís Vives I y hermana de Pau Vives, ambos también corredores $^{48}$. Daniel y Esperança tuvieron un hijo y al menos una hija ${ }^{49}$. El varón, Joan Valleriola II (m.1480), mercader y ciudadano de Valencia, contrajo matrimonio antes de 1443 con Damiata Pelegrí, con la que tuvo dos hijas y un hijo ${ }^{50}$. En 1478 había fallecido Damiata y Joan se casó

48 Cf. supra nota 42.

49 En un testamento otorgado en 1462, Joan Valleriola II hizo un legado de ropa de luto a favor de cierto Bernat Roca, cunyat meu, del que no tenemos por el momento más noticias, pero que podría señalar la existencia de una segunda hija ya fallecida en esa fecha (ACCV, P 11368. Notario Manuel d'Esparça. 1462, septiembre 28).

50 En torno a esa fecha nació la primogénita de la pareja, Esperança Valleriola, que cuando fue procesada por la Inquisición en 1523 declaró tener más de 80 años, lo que 
en segundas nupcias con Constança, hija del difunto mercader mallorquín Lluís Bellviure ${ }^{51}$. Joan murió apenas dos años después sin haber engendrado más descendencia.

Altadona Valleriola, debió casarse por esas mismas fechas con Jaume Castellar, corredor, hijo del calcetero Joan Castellar, dado que la hija de ambos, Aldonça, nació en torno a 1444. En 1464 esta Aldonça Castellar se casó a su vez con Galceran Nadal, calificado entonces como mercader, hijo del corredor Manuel Nadal, ciudadano de Valencia $^{52}$. En los años siguientes, Galceran protagonizó un caso de éxito social que resulta llamativo tanto por su condición de mercader como de converso. Cuando la nueva Inquisición se instaló en Valencia era reconocida su condición de caballero y fue uno de los escasos

remontaría su nacimiento hasta 1443 (Inq. leg. 1175, caja 2, s.n., s.f.). Sin embargo, en 1506 había dicho a los inquisidores que tenía 53, lo que retrasaría su nacimiento hasta 1453; José M. ${ }^{a}$ Cruselles Gómez, Enrique Cruselles Gómez y José Bordes García, Conversos de la ciudad de Valencia. El censo inquisitorial de 1506 (Valencia: Institució Alfons el Magnànim, 2015) pág. 376 [en adelante Conversos de Valencia]; pero de haber nacido en 1453 hubiera contado solamente seis años de edad cuando se concertó su matrimonio con Lluís Vives II en 1459 (ACCV, P 11371. Notario Manuel d'Esparça. 1466, julio 29), y parece más acorde con las costumbres de la época que, habiendo nacido en 1443 , se casara con 16 años cumplidos.

51 El acuerdo matrimonial fue otorgado el 17 de febrero de 1478 por la propia Constança, con el beneplácito de sus dos hermanos varones, Pere y Daniel Bellviure, y el monto de la dote ascendió a 500 libras valencianas (ACCV, P 11381. Notario Manuel d'Esparça). Se trataba del primer matrimonio de Constança, cuya edad en aquel momento desconocemos. Se trasladó a Valencia acompañada por su hermana Violant, y ambas se instalaron en la casa familiar de los Valleriola, en el carrer del Vall, donde la convivencia se vio pronto enrarecida por sus desavenencias con la nuera de Joan, Isabel Santàngel, que esta misma refirió a los inquisidores como parte de la estrategia defensiva adoptada en su primer proceso ( $c f$. infra nota 60 ).

52 En esa fecha, y una vez acordado el pago de su dote, Aldonça Castellar declaró haber cumplido los veinte años de edad para poder absolver a su padre, Jaume Castellar, y a su abuelo, Daniel Valleriola I, de sus funciones como tutores y curadores testamentarios suyos, que habían asumido tras la prematura muerte de su madre, Altadona. Por entonces, Jaume Castellar ya había tomado una segunda esposa, Violant, y cumplió con la obligación de devolver la dote de su primera mujer pagando, precisamente, una parte de la dote de su hija Aldonça (110 libras), a quien dicha cantidad correspondía como heredera de su madre. La otra parte de la dote de Aldonça, no mucho menor (90 libras), la aportó su tío Joan Valleriola II (ACCV, P 11369. Notario Manuel d'Esparça. 1464, febrero 24 y octubre 16). 
miembros del estamento nobiliario procesados por el tribunal a finales del siglo Xv; por entonces ya había fallecido Aldonça Castellar y Galceran tenía una segunda esposa, Úrsula, que en la documentación inquisitorial recibe el tratamiento de «magnífica» ${ }^{53}$.

Joan Valleriola II tuvo dos hijas y un hijo de su primera esposa, Damiata Pelegrí: Esperança, Beatriu y Daniel. Esperança Valleriola (1443c.1524), la mayor de ellos, contrajo matrimonio en 1459 con Lluís Vives II (m.c.1505) ${ }^{54}$, mercader y ciudadano de Valencia, hijo de Manuel Vives (m.1482), mercader, e Isabel de Conca. Esperança y Lluís fueron los padres de Lluís Vives III (c.1467-1524), Jeroni Vives (n.c.1475) y Leonor Vives (n.c.1485). El primero de ellos, dedicado también al comercio, contrajo matrimonio en los últimos años del siglo xv con Blanca, hija del mercader Jaume Marc, y el mayor de sus seis hijos fue el filósofo Joan Lluís Vives (1493-1540) ${ }^{55}$.

Por su parte, Beatriu Valleriola (m.c.1474) se casó hacia 1464 con el mercader Gabriel Sabata, hijo del también mercader Manuel Sabata y de su esposa Esperança Bellpuig. Beatriu y Gabriel tuvieron tres hijos: Manuel (n.c.1467), Damiata (n.c.1472) y Castellana (n.c.1474). El nacimiento de esta última y el fallecimiento de Beatriu se produjeron en fechas próximas, lo que permite pensar que ambos hechos estuvieron

53 Aldonça Castellar falleció antes que Joan Valleriola II (m.1480), quien heredó sus bienes (Inq. leg. 1138, caja 4, s.n., s.f.). El proceso contra Galceran Nadal, miles neophitus, fue abierto en septiembre de 1486 en base a hechos que habrían ocurrido quince años antes. La intervención del gobernador del Reino no le libró de un arresto domiciliario que se prolongó hasta 1489 , sin que conozcamos de momento los términos de la sentencia. Su matrimonio con Úrsula y el tratamiento otorgado a esta permite suponer un enlace hipergámico que habría consolidado el éxito económico de Galceran y la consiguiente adquisición del rango de caballero (Inq. leg. 923, caja 2, s.n., s.f.)

${ }^{54}$ El 11 de septiembre de 1504, Lluís Vives II ratificó ante el tribunal de la Inquisición las confesiones que había hecho en 1491, en las que implicaba a sus suegros y otras personas (Inq. leg. 1014, caja 1, s.n., s.f.). Ya había fallecido en 1506, cuando su esposa, Esperança Valleriola, declaró para el censo de conversos realizado por la Inquisición en esa fecha; Conversos de Valencia, pág. 376.

55 Véanse las declaraciones del mercader Lluís Vives III y de su madre, Esperança Valleriola, recogidas en el censo inquisitorial de 1506 (Conversos de Valencia, págs. 243-244 y 376-377); y también el proceso contra dicha Esperança, llevado a cabo entre 1523 y 1524 (Inq. leg. 1175, caja 2, s.n., s.f.). El linaje de esta familia Vives ha sido reconstruido por García (Els Vives, págs. 122-130 y 219-224); cf. supra notas 13 y 42. 
relacionados ${ }^{56}$. Gabriel Sabata volvió a casarse poco después (c.1475) con Violant Miró, hija de un mercader mallorquín, con la que tuvo otros cinco hijos nacidos entre 1480 y $1491{ }^{57}$.

Daniel Valleriola III, calificado como mercader y pañero (draper), fue el único hijo varón de Joan Valleriola II. En 1465 contrajo matrimonio con Isabel Santàngel (c.1451-1524), hija del mercader Alfons Santàngel ${ }^{58}$. La novia no contaba más de 13 o 14 años, una edad exigua incluso para las costumbres de la época. Tuvieron solamente una hija, Damiata Valleriola (n.c.1468), que a finales de 1485 se casó con un doncel de Sagunto, Joan de Sant Feliu, sin que sepamos si tuvieron descendencia ${ }^{59}$. Las circunstancias que rodearon este acuerdo matrimonial, particularmente conflictivas, condujeron al primer procesamiento de Isabel Santàngel por el Santo Oficio en $1486^{60}$.

56 Castellana fue criada de llet por Caterina, una esclava tunecina que su padre debió comprar para la ocasión y que estuvo en la casa hasta 1485, cuando Gabriel le dio la libertad en pago a los servicios prestados. Sus declaraciones, junto con otras, forman parte del proceso inquisitorial contra Damiata y Castellana Sabata, abierto en 1497 a cuenta de los delitos heréticos cometidos en casa de sus padres cuando contaban entre seis y ocho años de edad. Salieron bien libradas en comparación con otros parientes acusados de cargos no mucho más graves: durante tres años debían escuchar el sermón pronunciado en la eucaristía cada domingo y día festivo (Inq. leg. 1006, caja 1 , s.n., s.f.).

57 Conversos de Valencia, págs. 469-470. Violant Miró era sobrina de otro mercader de origen mallorquín, Gaspar Valleriola, a quien nos referiremos luego.

58 No nos consta que esta familia guardara parentesco alguno con el financiero Lluís Santàngel, muy activo por esa época en Valencia, ni con sus hijos Lluís y Jaume Santàngel, estrechamente vinculados a la administración fernandina en las últimas décadas del siglo Xv.

59 Joan de Sant Feliu era descendiente de un linaje de caballeros cuyos miembros están ampliamente documentados desde el siglo XIV en el ejercicio de los cargos municipales de Sagunto, particularmente en el justiciazgo, cuyo nombramiento constituía una prerrogativa del Consell de Valencia.

${ }^{60}$ Isabel sufrió dos procesos inquisitoriales, y aunque pudo salir bien parada del primero (1486-1487), en buena medida gracias a su juventud, el segundo -mucho más expeditivo y cruel- la llevó a la hoguera en 1524 (Inq. leg. 986, caja 2; leg. 1129, caja 1; leg. 1170, caja 1; leg. 1175, caja 2). Su nombre está incluido en los índices de procesados, dentro de la lista de relajados al brazo secular, con fecha de 1524 (Inq. leg. 5320 , caja 2, exp. 12, fol. 15). 
En abril o mayo de 1484, Daniel Valleriola III emprendió un viaje por mar a Nápoles cuyas razones no están claras. Teniendo en cuenta que, junto con su esposa, se había acogido al primer edicto de gracia promulgado por la nueva Inquisición en mayo de $1482^{61}$, cabe la posibilidad de que, más allá de otros motivos comerciales, quisiera alejarse de Valencia antes de que llegara el nuevo inquisidor enviado por el monarca, el aragonés fray Juan de Épila, pues en la ciudad se temía -como de hecho sucedió- un endurecimiento de la represión ${ }^{62}$.

Tras la marcha de Daniel, Isabel Santàngel permaneció en la casa familiar, situada en la calle del Mar, en compañía de su hija Damiata, de la abuela de su marido, Esperança Vives, mujer de avanzada edad, y de dos sirvientes: Gràcia Barbero y lo fadri apellat Johanot. Con la colaboración de estos dos últimos, Damiata fue raptada del domicilio en lo que parece ser un matrimonio por secuestro, pues poco más tarde comenzó a negociarse su casamiento con Joan de Sant Feliu, quien a juzgar por testimonios posteriores había jugado un papel bastante equívoco en los hechos ${ }^{63}$. En cualquier caso, Isabel Santàngel denunció el secuestro ante el gobernador del Reino y aportó una lista con más de veinte sospechosos, algunos de los cuales fueron encarcelados y sometidos a las prácticas habituales de tortura judicial. El notario Joan Pla, que en 1486 ejerció la defensa de Isabel ante el Santo Oficio, no dudaba en achacar al rencor de aquellos la denuncia contra su patrocinada, que consideraba del todo falsa ${ }^{64}$.

${ }^{61}$ Aunque el edicto fue promulgado en la fecha indicada, la burocracia inquisitorial tardó meses en recabar las confesiones de quienes se acogieron a él; las de Daniel e Isabel no se registraron hasta el 21 de julio de 1483; Enrique CRUSElles Gómez, «El primer edicto de gracia del tribunal inquisitorial de Valencia (5 de mayo de 1482)», eHumanista/Conversos 7 (2019) págs. 275-297: 297.

${ }^{62}$ Los jurados escribían en este sentido al rey Fernando el 14 de junio de 1484: Sabent que vénen a aquest vostre regne mestre Épila e los ministres de la Inquisició, molts convesos se'n van, e altres trahen los més béns que poden [...]; Agustín RuBio Vela, «Valencia y Torquemada. En torno a los comienzos de la Inquisición española (1482-1489)», Boletín de la Sociedad Castellonense de Cultura 74 (1998) págs. 116-117.

${ }^{63}$ Se trata de las declaraciones producidas en el primer proceso inquisitorial contra Isabel, iniciado unos seis meses después de la boda de su hija, a raíz de las denuncias presentadas por algunos de los implicados en el secuestro de la novia.

64 Véase el escrito de alegaciones del defensor (Inq. leg. 1129, caja 1, s.n., fols. 17-18) y el testimonio de García de Huete, alcaide de Alcorisa, en el reino de Aragón 
Daniel Valleriola III nunca regresó de Nápoles, donde -a decir de diversos testigos recabados en el primer proceso contra su esposa Isabelhabía muerto poco después de llegar sin que se conocieran las circunstancias. Con él se extinguió por vía masculina este primer linaje de conversos Valleriola, el que contó entre sus descendientes a Joan Lluís Vives y cuyos orígenes se remontaban a la antigua Judería valenciana.

\section{Tres mercaderes mallorquines en Valencia}

Los libros de avecindamientos de Valencia dan cuenta de dos mercaderes conversos que, procedentes de Mallorca, se trasladaron a la ciudad en los años centrales del siglo xv. Gaspar y Gilabert Valleriola se domiciliaron en 1450 y 1455, respectivamente, en la parroquia de Sant Tomàs, que comprendía una parte importante de la antigua Judería ${ }^{65}$. Los vínculos familiares entre los conversos valencianos y mallorquines se remontaban a los tiempos anteriores a la conversión y se apoyaban en una red de estrechas relaciones comerciales que se extendía hasta los puertos del reino de Granada y el norte de África ${ }^{66}$. La transferencia de individuos entre ambas comunidades, de la que existen numerosos ejemplos antes de 1391, continuó posteriormente entre los conversos de ambos territorios ${ }^{67}$.

(Inq. leg. 1129, caja 1, s.n., fols. 30-31). Este era hermano del fadrí Joanot que servía en casa de Isabel Santàngel y que, acusado por esta de colaborar en el secuestro de su hija, se contaba entre los encarcelados por el gobernador. En su declaración ante el Santo Oficio, García afirmó que otro de los implicados, Joan Barbero, que era el padre de la sirvienta Gràcia y había sido torturado en prisión, le propuso denunciar a Isabel ante el Santo Oficio, a fi que puguessen pendre vengança de la dita Ysabel los dits delats e lo germà de ell testimoni. García declaró haberse negado porque no quería denunciar a nadie falsamente. Por último, fue dicha Gràcia Barbero quien denunció a Isabel como sospechosa de herejía, pasando a engrosar la larga lista de sirvientes domésticos que el tribunal utilizó como delatores (Inq. leg. 1170, caja 1, s.n., fols. 5-6).

65 Gaspar se instaló davant casa de mossén Pere Maresme; Gilabert a la plaça dels Cabrerots; M. ${ }^{a}$ Desamparados Cabanes Pecourt, (ed.), Avecindados en la ciudad de Valencia en la época medieval. Avehinaments (1308-1478) (Valencia: Ajuntament de València, 2008) págs. 352 y 360.

${ }^{66}$ Hinojosa Montalvo, En el nombre de Yahveh, págs. 531-532.

${ }^{67}$ En Mallorca residían miembros de la familia Abnayub (Hinojosa Montalvo, En el nombre de Yahveh, pág. 180), que como hemos visto había adoptado en Valencia los apelli- 
En 1453, el mallorquín Gilabert Valleriola había acordado su matrimonio con la valenciana Damiata, hija del corredor converso Bonanat Muncada. La dote, que se hizo efectiva en marzo de 1455, el mismo año en que Gilabert se avecindó en Valencia, ascendía a 350 libras, una cantidad acorde con las costumbres de los ambientes mercantiles acomodados a los que pertencían ambos contrayentes ${ }^{68}$. Apenas unos meses más tarde, la muerte de Bonanat Muncada convirtió a Damiata en heredera universal de sus bienes ${ }^{69}$, lo que proporcionó a Gilabert un beneficioso incremento de los apoyos financieros de sus actividades comerciales en Valencia. No tenemos constancia de que el matrimonio tuviera descendencia.

Desde que llegó a Valencia, y según se desprende de sus propias confesiones ante la Inquisición, Gilabert se introdujo en el círculo doméstico del mercader Joan Valleriola II. Esto permite pensar que pudo existir entre ambos algún tipo de parentesco, aunque lo bastante lejano como para que no se hiciera explícito en la documentación inquisitorial ${ }^{70}$. Fruto de esa cercanía fue su amistad con los yernos de Valleriola, los mercaderes Lluís Vives II y Gabriel Sabata ${ }^{71}$.

La proximidad de Gilabert Valleriola y su esposa a la familia Valleriola-Vives terminó implicándoles en los procedimientos inquisitoriales

dos Mas, Pardo y algún otro. También se han documentado en Valencia algunos conversos mallorquines como Arnau Llobregat [Abraham Cohen] en 1392, Pere Marçal en 1402 y el mercader Pere Planella, que en 1400 era calificado como ciudadano de Mallorca y en 1401 como ciudadano de Valencia; Luz Company, Evolución y estrategias, págs. 192-193 y 199.

68 Hinojosa Montalvo, «Los Muncada», pág. 384.

69 Tenemos noticia del testamento de Bonanat a través del contrato de compraventa de una casa en la calle del Mar realizado en 1491, al que nos referiremos luego.

${ }^{70}$ En 1491 Gilabert se acogió, como su esposa Damiata, al último de los periodos de gracia otorgados por el tribunal de Valencia. En sus declaraciones ambos incluyeron los ayunos de Yom Kipur que se celebraban en casa de Joan Valleriola II y la identidad de los familiares y amigos que participaban en ellos, con particular referencia a las lecturas públicas que hacía el cabeza de familia en una biblia de su propiedad escrita en lengua vulgar (Inq. leg. 801, caja 1, exp. 9, fol. 39v).

${ }^{71}$ Hacia 1464, Gilabert Valleriola y su esposa Damiata Muncada viajaron a Sagunto en compañía de Lluís Vives II y Esperança Valleriola. Los cuatro hicieron entonces una visita a la sinagoga saguntina de la que muchos años más tarde se vieron obligados a dar explicaciones ante el tribunal del Santo Oficio. Es destacable, asimismo, la presencia de ambos cónyuges en los duelos familiares de la familia Sabata (Inq. leg. 802, caja 2, s.n., fols. 244-246). 
abiertos contra esta a partir de 1486. Resulta llamativo, sin embargo, que Gilabert no se acogiera a ningún edicto de gracia con anterioridad al de mayo de 1491, el último de los promulgados por el tribunal de Valencia, quizás porque hasta entonces no se había sentido verdaderamente amenazado ${ }^{72}$. En enero de ese mismo año 1491, unos meses antes de confesar sus culpas, el matrimonio vendió una casa que poseía en la calle del Mar a uno de sus vecinos, lo que podría considerarse como un indicio de su decisión de abandonar la ciudad ${ }^{73}$.

Las confesiones de ambos cónyuges fueron recogidas el 4 de junio siguiente. La de Damiata Moncada, que alegó enfermedad para no acudir personalmente a las dependencias del Santo Oficio, fue recogida en un escrito entregado por su marido. Unos días más tarde, un notario del tribunal que acudió a su domicilio (también situado en la calle del Mar) para tomarle juramento, confirmó que seguía indispuesta. Ninguno de los dos volvería a comparecer. En 1502, la Inquisición utilizó sus confesiones de 1491 en los procesos contra la memoria y fama de Joan Valleriola II y de su hija Beatriu, pero Gilabert y Damiata no pudieron corroborarlas porque, según las escuetas indicaciones del escribano, habían fallecido. Quizás la enfermedad de Damiata dio al traste con un plan de fuga y ambos terminaron siendo víctimas de la peste que azotaba la ciudad por aquellas fechas, o tal vez huyeron y el tribunal los dio por muertos en algún lugar lejano... Mientras no dispongamos de nuevas informaciones, solo cabe especular.

Tampoco tenemos indicio alguno de que entre ambos inmigrantes mallorquines, Gilabert y Gaspar Valleriola I, existieran vínculos de pa-

${ }^{72} \mathrm{Su}$ esposa, Damiata Moncada, sí había confesado con anterioridad. En 1486, durante el primer proceso contra Isabel Santàngel, una sirvienta de ésta trajo a colación algo que había oído decir a una esclava de Gilabert Valleriola. Atemorizada sin duda por las graves consecuencias que podían derivarse de aquel peligroso juego de rumores, Damiata se acogió al edicto de gracia de 1488. Posteriormente se vio obligada a reconocer que su confesión de entonces no había sido completa y volvió a acogerse, esta vez con su marido, al edicto de 1491 (Inq. leg. 802, caja 2, s.n., fol. 244).

73 ARV, P 1856. Notario Jaume de Prats. 1491, enero 5. Llama la atención que el comprador fuera precisamente el caballero Joan Claver, receptor de bienes confiscados de la Inquisición entre marzo de 1487 y octubre de 1491; José M. ${ }^{a}$ Cruselles, "La primera contabilidad inquisitorial. El fondo del Archivo del Reino de Valencia (14821527)», en En el primer siglo de la Inquisición española. Fuentes documentales, procedimientos de análisis, experiencias de investigación, coord. José M. ${ }^{a}$ Cruselles GómeZ (Valencia: Publicacions de la Universitat de València, 2013) págs. 221-249. 
rentesco consanguíneo, aunque sí tenían negocios comunes ${ }^{74}$. Gaspar, que en 1450 era calificado como mercader y ciudadano de Valencia, sustentaba sus operaciones comerciales en una destacada actividad como armador y navegante ${ }^{75}$. Tenía dos hermanos que actuaban como agentes comerciales suyos: Francesc Valleriola, ciudadano de Mallorca, a quien en 1450 nombró representante legal tanto para asuntos comerciales como judiciales ${ }^{76}$; y Daniel Valleriola II, que patroneaba las naves de la empresa y ejercía como factor en los puertos del Magreb. También en torno a 1450, Daniel se había casado en Valencia con Brianda, hija del cambista Lluís Belluga, aunque poco después había marchado a Orán, donde actuaba en 1451 como agente de su hermano Gaspar ${ }^{77}$.

Los tratos comerciales entre Gaspar Valleriola I y Joan Valleriola II, que podemos rastrear en la documentación notarial desde al menos 1451, permiten pensar que también pudo existir entre ambos una relación de consanguinidad que, aun siendo bastante indirecta, pudo facilitar el asentamiento del mallorquín en Valencia ${ }^{78}$. Sí hemos podido documen-

${ }^{74}$ Jacqueline Guiral-Hadziosif, Valencia, puerto mediterráneo en el s. XV (14101525) (Valencia: Edicions Alfons el Magnánim, 1989) pág. 243. Gilabert actuó en 1461 como avalista de Gaspar, pero cuando la autora afirma que ambos eran familiares se fundamenta tan solo en la coincidencia de sus apellidos.

75 Era propietario y patrón de una galera en 1456, y propietario de una carabela en 1461; GuIral-HadziIosif, Valencia, puerto mediterráneo, págs. 242-243.

76 ACCV, P 25958. Notario Pere Castellar. 1450, diciembre 16.

77 La fecha del matrimonio podemos deducirla de los registros inquisitoriales, donde se indica que el primer hijo de Daniel y Brianda, Lluís Valleriola I, habría nacido en torno a 1452. El propio Daniel declaró que apenas transcurridas tres semanas desde la boda, se marchó a Orán y Tremecén, donde permaneció durante casi un año (Inq. leg. 1014, caja 1, s.n., fols. 31v-32; leg. 1014, caja 1, s.n., fol. 31v). A finales de 1451, Gaspar Valleriola fletó en Valencia la carabela de Gaspar Palau, un patrón local, para llevar diversos productos -algodón, tártaro, greda, hoja de cáñamo y otros- a Orán, donde su hermano Daniel tendría que decidir, una vez descargada la nave, si debían enviarla a Honaine a cargar para el viaje de vuelta (ACCV, P 25975. Notario Pere Castellar. 1451, diciembre 7).

78 En 1451, el corredor Daniel Valleriola I actuó como testigo en el protesto de una letra de cambio girada desde Barcelona, cuyo pago reclamó Gaspar Valleriola en la Lonja de Valencia al mercader mallorquín Antoni de Tèrmens y que este se negó a satisfacer. Unos meses después, Gaspar Valleriola participó en un seguro marítimo contratado entre Joan Valleriola II y el también mercader valenciano Pere Eximénez, a cuenta de un cargamento de 200 quintales de pasa que debía viajar desde la Vila-Joiosa hasta Brujas 
tar, en cambio, el parentesco político -también muy indirecto- establecido entre estos dos mercaderes a través de la familia Nadal (fig. 3). Cuando en 1450 fue inscrito su avecindamiento en Valencia, Gaspar Valleriola ya había contraído matrimonio con Aldonça, hija del corredor Manuel Nadal y hermana de Galceran Nadal, el mercader convertido en caballero cuya primera esposa había sido Aldonça Castellar, nieta de Daniel Valleriola I y sobrina de Joan Valleriola II ${ }^{79}$. Aquel era el segundo matrimonio de Aldonça Nadal, casada antes con un platero llamado Vallebrera, un apellido que se le asigna a menudo en los papeles del Santo Oficio alternándolo con el de Valleriola ${ }^{80}$.

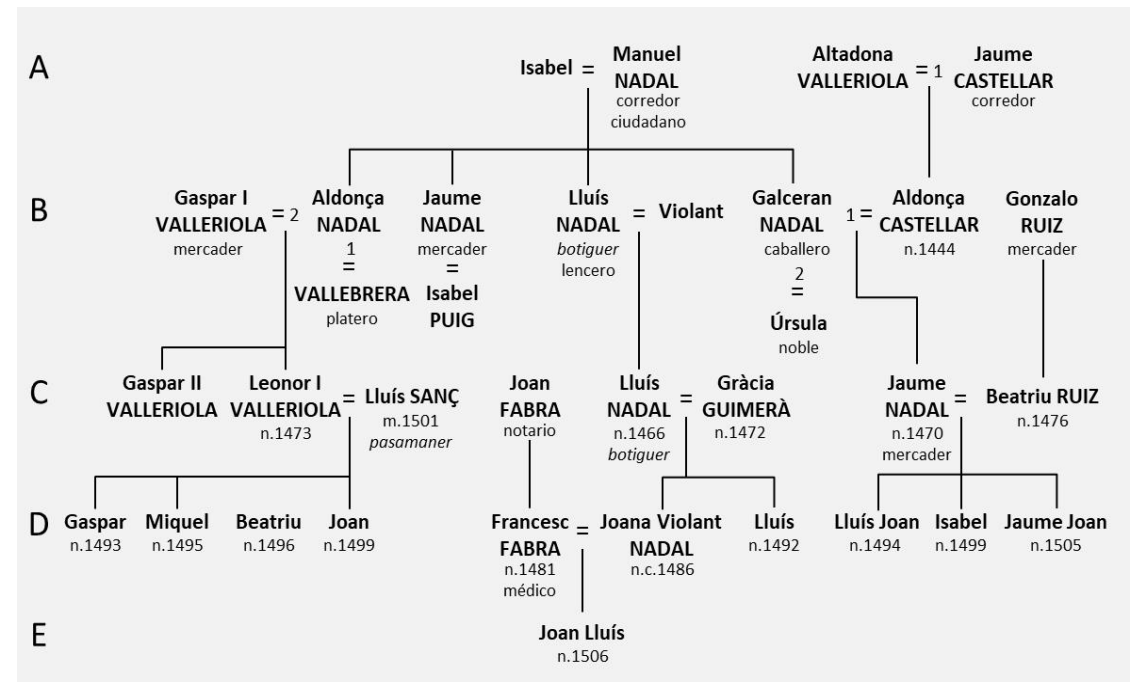

Fig. 3: La familia Valleriola-Nadal

Gaspar Valleriola I y Aldonça Nadal tuvieron, al menos, dos hijos y una hija. Tenemos noticia del médico Enric Valleriola por la reclamación que presentó ante el baile general del reino de Valencia en 1480, a cuenta

a bordo de cierta nave vizcaína (ACCV, P 25975. Notario Pere Castellar. 1451, abril 21 y octubre 12).

79 Cf. supra notas 52 y 53 .

${ }^{80}$ Así ocurre, sobre todo, en el proceso que se abrió contra la memoria y fama de dicha Aldonça Nadal en 1502, cuyo resultado desconocemos (Inq. leg. 996, caja 1, s.n., s.f.). 
del derecho de represalia impuesto quince años antes sobre el comercio portugués para resarcir a su padre de ciertos actos de piratería perpetrados contra una nave de su propiedad ${ }^{81}$. Ignoramos si el primogénito era este Enric o su hermano Gaspar Valleriola II, de quien solo sabemos que a finales de la centuria residía en Moixent ${ }^{82}$. La hija, Leonor Valleriola I (n.c.1473), se casó en 1490 o poco después con el pasamanero Lluís Sanç, hijo de un notario de Orihuela llamado Ramon Sanç, y tuvo con él cuatro hijos: Gaspar (n.1493), Miquel (n.1495), Beatriu (n.1496) y Joan (n.1499) ${ }^{83}$. Lluís Sanç fue procesado y quemado por la Inquisición en torno a $1501^{84}$.

\section{La familia Valleriola-Belluga y el tribunal del Santo Oficio}

Como hemos visto, tras contraer matrimonio con Brianda Belluga hacia 1450, el mercader mallorquín Daniel Valleriola II prosiguió sus viajes y estancias comerciales en el extranjero. Él mismo declaró ante la Inquisición que había marchado al norte de África tres semanas después de casarse y que residió allí durante un año. Tras regresar a Valencia, donde permaneció un tiempo indeterminado, se trasladó a Almería, donde dijo haber vivido tres años. Viajó más adelante al sur de Italia, residiendo durante año y medio entre Sicilia y Nápoles; y todavía mencionaba otra estancia en Portugal, aunque esta de solo cinco meses ${ }^{85}$.

Además de agente comercial, Daniel era hombre de mar, según explicó a los inquisidores para justificar sus largas ausencias. En 1462 patroneaba una carabela propiedad de su hermano, Gaspar Valleriola, que fue apresaba y robada en aguas de Berbería por la flotilla corsaria

81 Guiral-Hadzilosif, Valencia, puerto mediterráneo, pág. 88.

82 Así consta en la investigación genealógica que sobre algunos conversos difuntos hizo la Inquisición en un momento impreciso entre 1486 y 1500 (Inq. leg. 1138, caja 4, s.n., s.f.)

83 Conversos de Valencia, pág. 414.

84 Está incluido en los índices de procesos del tribunal de Valencia, dentro de la lista de quemados en persona, con dicha fecha de 1501 (Inq. leg. 5320, caja 2, exp. 12, fol. 23).

85 Inq. leg. 1014, caja 1, s.n., fol. 31v-32. 
del infante Fernando de Portugal ${ }^{86}$. Apoyados por el Consell de Valencia, los Valleriola y otros comerciantes perjudicados por aquel acto de piratería reclamaron ante los reyes de Portugal y Aragón. En este contexto se habría producido el viaje a Portugal del que Daniel Valleriola II hablaría más tarde a los inquisidores, y que hizo en compañía del mercader Pere Barceló a finales de 1462 o ya en 1463. Pero la demanda debió caer en saco roto, porque Gaspar Valleriola y el mencionado Pere Barceló instaron a continuación un proceso en la curia real aragonesa que se alargó durante todo el año 1464. En esta última fecha, Gaspar viajó a Barcelona acompañado por Joan Valleriola II, seguramente otro de los perjudicados, a fin de tratar directamente el asunto con el infante corsario $^{87}$. Por último, y ante la imposibilidad de llegar a un acuerdo, la Corona aceptó imponer un gravamen sobre el comercio portugués en el reino de Valencia para resarcir las pérdidas, que según Guiral habían ascendido a 15.000 florines.

Se ha conservado una parte significativa de los procesos inquisitoriales abiertos contra Daniel Valleriola II, calificado alternativamente como mercader o droguer, y contra su esposa Brianda Belluga. Ambos se acogieron en 1482 al primer edicto de gracia promulgado por el tribunal de Valencia ${ }^{88}$ y a algún otro posterior, ya que según testificó una vecina suya en 1499, habían salido dos o tres veces en las procesiones de penitenciados ${ }^{89}$. Pero aunque el Santo Oficio recogía habladurías sobre

${ }^{86}$ El hecho se recoge con detalle en un expediente compuesto en 1464 que terminó en los archivos del Santo Oficio, podemos suponer que a consecuencia de los procedimientos abiertos contra dicho Daniel Valleriola II (Inq. leg. 5320, caja 2, exp. 13, fols. 10-52). Acerca del desarrollo del incidente y de las posteriores negociaciones y consecuencias políticas, véanse GuIRAL-HadziIOSIF, Valencia, puerto mediterráneo, págs. 145, 243 y 536, y Andrés Díaz Borrás, El ocaso cuatrocentista de Valencia en el tumultuoso Mediterráneo (1400-1480) (Barcelona: CSIC, 2002) págs. 279-283.

87 Contaron para la ocasión con un salvoconducto extendido a nombre de ambos por el condestable Pedro de Portugal, a quien el Consell del Principat, en su enfrentamiento con Juan II de Aragón, había reconocido por entonces como rey de los catalanes; Jesús Ernesto Martínez Ferrando, (ed.), Catálogo de la documentación de la cancillería regia de Pedro de Portugal, vol. II (Madrid: Dirección General de Archivos y Bibliotecas, 1953) pág. 146.

88 Enrique Cruselles Gómez, «El primer edicto de gracia», pág. 297.

89 (...) estant ses vehins ells se abjuraren e anaren en la professó dos o tres voltes; y que lo Valleriola se anava açotan en la professió (Inq. leg. 893, caja 1, s.n., s.f.) 
ellos desde 1485, no fueron procesados hasta $1497^{90}$. Una vez concluidas, ambas causas fueron presentadas el 6 de octubre de ese año ante el consejo de juristas que asesoraba al tribunal, donde se decidió por unanimidad admitirlos a reconciliación con abjuración, penitencia pública y pena de cárcel al arbitrio del inquisidor ${ }^{91}$. El auto de fe tuvo lugar en la catedral de Valencia el 28 de octubre. Daniel y su esposa Brianda, junto con la hermana de esta, Beatriu Belluga, y Leonor, esposa del botiguer Joan Celma, los cuatro ataviados con sambenitos y portando cirios verdes en la mano, fueron subidos a una tarima para oír una sentencia cuyos pormenores desconocemos ${ }^{92}$. Es probable que estuvieran un tiempo en la cárcel o bajo arresto domiciliario, pero según el testimonio prestado por la mencionada vecina en 1499 , por lo demás bastante confuso en términos cronológicos, Daniel Valleriola II habría embarcado hacia Nápoles en 1498, después de abjurar, y és mort allà, segons dien. No hemos podido confirmar este hecho por ninguna otra vía, de manera que el evidente paralelismo que este relato guarda con lo sucedido a Daniel Valleriola III en 1484, conduce a preguntarnos si algunos testigos del tribunal no pudieron haber caído, como tantos historiadores después, en las trampas de la homonimia ${ }^{93}$. En todo caso, Brianda no acompañó a su marido al exilio, y aunque la Inquisición siguió recogiendo testimonios contra ella, no tenemos constancia de que volviera a ser procesada durante su vida.

A pesar de los frecuentes viajes de Daniel Valleriola II, su matrimonio con Brianda Belluga resultó bastante prolífico (fig. 4). Entre 1452 y 1484 les nacieron siete hijos que alcanzaron la edad adulta y algunos otros que no superaron el periodo neonatal ${ }^{94}$. Aunque en diversa medida,

${ }^{90}$ Fueron incluidos con esa fecha en la lista general de procesados, que excluía a quienes habían sido enviados a la hoguera en persona, efigie o post mortem (Inq. leg. 5320, caja 2, exp. 10, fols. 10r y 17r).

91 Inq. leg. 1162, caja 3, s.n., s.f.; y leg. 1014, caja 1, s.n., s.f.

92 Inq. leg. 1094, caja 2, s.n., s.f.

${ }^{3}$ Cf. supra notas 61 y 62 .

94 Según sus propias confesiones en el proceso abierto contra ella en 1497, Brianda habría recibido en cierta ocasión la visita de Aldonça Nadal, esposa de su cuñado Gaspar Valleriola, que le aconsejó celebrar la Pascua de los judíos perquè se·l morian les criatures que tenia, que si fehia la Pascua dels juheus que le bivirian los fills (Inq. leg. 943, caja 1, s.n., s.f.) No sabemos cuándo se produjo este encuentro, pero en 1467 
todos los supervivientes verían alteradas sus vidas por la persecución inquisitorial.

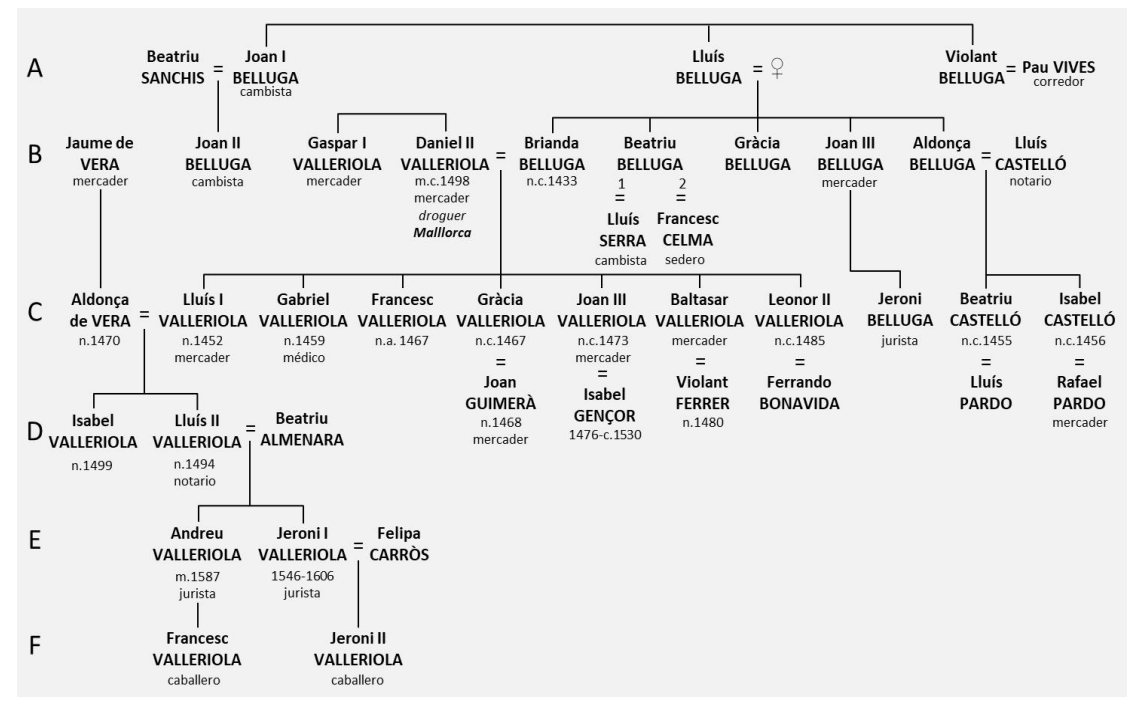

Fig. 4: La familia Valleriola-Belluga

El hijo primogénito, Lluís Valleriola I, siguió los pasos de su padre en el mundo de los negocios. Nacido en torno a 1452, contrajo matrimonio hacia 1490 -a la avanzada edad de 38 años- con Aldonça, de 20 años de edad, hija del mercader Jaume de Vera, con la que tuvo dos hijos: Lluís Valleriola II (n.1494) e Isabel Valleriola (n.1499). En 1491, Aldonça de Vera fue procesada por la Inquisición a cuenta de ciertos rituales judaicos celebrados en casa de su madre diez años antes. No conocemos la sentencia dictada contra ella, pero aunque el fiscal pidió prisión perpetua, el nacimiento de su primer hijo tres años más tarde confirma que pudo salir de aquel trance relativamente bien librada ${ }^{95}$. En 1506, Aldonça y sus hijos vivían en casa de un hermano de ella, el botiguer Lluís Amorós de Vera, pues Lluís Valleriola I se encontraba en

Brianda otorgó un testamento nunca publicado en el que mencionaba a sus cuatro hijos mayores: Lluís, Gabriel, Francesc y Gràcia (ACCV, P 11372. Notario Manuel d'Esparça. 1367, octubre 8).

95 Inq. leg. 1070, caja 2, s.n., s.f. 
Nápoles, sin que sepamos si se ocupaba allí de asuntos mercantiles o solo intentaba mantenerse alejado de la Inquisición ${ }^{96}$. En cualquier caso, el hecho de que ninguna declaración suya fuera incluida en los procesos abiertos contra sus padres y hermanos entre 1497 y 1531 , apunta a que su ausencia terminó resultando definitiva ${ }^{97}$.

El segundo hijo de Daniel y Brianda fue Gabriel Valleriola (n.c.1459). Las circunstancias que rodearon su nacimiento fueron objeto, en 1485, de una de las primeras encuestas inquisitoriales contra la familia, pues era un hecho conocido en la ciudad -y los inquisidores no tardaron mucho en saberlo- que su madre lo alumbró ya circunciso, cuando toda la familia se había desplazado a Sagunto para alejarse de la peste declarada en la capital ${ }^{98}$. Alcanzada la edad juvenil, Gabriel no continuó la tradición comercial de la familia, sino que optó por los estudios superiores y la práctica de la medicina. Estuvo en las universidades de Lleida, Montpellier y Pisa, donde finalmente se doctoró en $1481^{99}$. Como mu-

96 Conversos de Valencia, pág. 209. Sobre la actividad comercial desarrollada en Valencia por Lluís Valleriola I antes de su partida, véase David Igual LuIs, «Los mercaderes toledanos en los reinos hispánicos (1475-1520): una aproximación a partir del observatorio valenciano», Anuario de Estudios Medievales 48:1 (2018) págs. 243-269.

97 En 1487 el tribunal recogió el testimonio de cierto barbero llamado Domingo de Urbieta, quien dijo sospechar que, veinte años antes (c.1467), Daniel Valleriola II había celebrado el ayuno del Yom Kipur junto con sus hijos Lluís y Gabriel (Inq. leg. 801, caja 1, exp. 9, fols. 99v-100). Aunque esta delación no tuvo efecto inmediato, no cabe duda de que quienes se sabían en peligro a causa del constante trasiego de rumores malintencionados, pudieron considerar que había llegado el momento de prestar más atención a sus negocios en el extranjero. Así Lluís Valleriola I -quien según el mencionado testigo pasaba el día en la tienda paterna- pudo, como otros muchos, verse animado a expatriarse por motivos "comerciales"; una decisión que, por lo demás, estaba en consonancia con la tradición viajera de la familia.

98 Inq. leg. 801, caja 1, exp. 9, fols. 97-99v.

${ }_{99}$ M. Gabriel Danielis Valleriola de Valentia studens artibus et medicinae, superó con éxito el examen del Colegio de Artes y Medicina el 11 de diciembre de 1481, fue declarado doctor públicamente por el vicario episcopal de Pisa y se le entregaron las insignias doctorales; Armando F. VerDE, Lo Studio fiorentino, 1473-1503. Ricerche e documenti, vol. II: Docenti-Dottorati (Florencia: Istituto Nazionale di Ricerche sul Rinascimento, 1973) págs. 678-679, y Pilar Codonyer Soria, Estudiantes valencianos al Studio Fiorentino (1473-1494) (València: Universitat de València, 2003) págs. 112-113: este último trabajo recoge los hitos fundamentales de la carrera universitaria de Gabriel y hace referencia a las actividades comerciales de su padre, Daniel Valleriola II, aunque por efecto de la ho- 
chos universitarios de la época, es probable que volviera inmediatamente a Valencia para ejercer su nueva profesión y comenzar a resarcirse de la fuerte inversión económica que habían supuesto los años de estancia en el extranjero ${ }^{100}$. Su regreso, sin embargo, coincidió con el inicio de las actividades de la nueva Inquisición, y aunque en los primeros momentos su familia no había llamado la atención del tribunal, pronto se convertiría en objeto de peligrosas habladurías. En 1485, cuando los inquisidores hacían preguntas sobre las sospechosas circunstancias de su nacimiento ${ }^{101}$, Gabriel se encontraba en la ciudad y trató de influir en el desarrollo de la investigación aportando de manera subrepticia algún testigo que hablara en su favor ${ }^{102}$. A partir de ese momento solo tenemos de él noticias indirectas. Nunca compareció ante el tribunal, probablemente porque se fue de Valencia antes de que sus padres fueran encausados en 1497; quizás antes incluso de que Aldonça de Vera, la mujer de su hermano Lluís, fuera detenida en 1491. La decisión fue acertada, pues era cuestión de tiempo que el Santo Oficio procediera contra él. Su nombre aparece, con fecha de 1499, en la lista «de las personas que han sido condenadas en estatua por ausentes y relaxadas al braço secular y citadas en absentia ${ }^{103}$. No tenemos noticia de su paradero, pero parece probable que eligiera Nápoles, al igual que su hermano Lluís, quien sin embargo nunca fue reclamado por el tribunal.

monimia incluye a ambos en la familia Valleriola-Vives y, peor aún, vincula esta última con aquellos otros ciudadanos y nobles descendientes del viejo banquero Arnau Valleriola, con quienes nunca mantuvo parentesco alguno de alianza o consanguinidad.

100 José M. ${ }^{a}$ Cruselles Gómez, "Valencianos en la universidad de Bolonia. Rentabilización social de los estudios superiores a finales del siglo XV», en Lluís de Santàngel $i$ el seu temps. Congrés internacional. Valencia, 5 al 8 d'Octubre 1987 (Valencia: Ajuntament de València, 1992) págs. 388-400.

101 Por lo que sabemos hasta ahora, la primera noticia que tuvieron los inquisidores acerca de la circuncisión de Gabriel procedía de un primo hermano de su madre, el cambista Joan Belluga II, que en septiembre de 1485 declaró no haber cometido falta alguna contra la fe cristiana, pero interrogado luego acerca de otras personas acabó comprometiendo a su pariente (Inq. leg. 941, caja 1, s.n., s.f.)

102 Como una antigua sirviente de la familia reveló a poco que fue presionada, Gabriel la había inducido a comparecer; y aunque añadió que nunca le había dicho qué debía testificar, no cabe duda de que el descubrimiento de la argucia empeoró las sospechas del tribunal (Inq. leg. 1031, caja 1, s.n., s.f.)

103 Inq. leg. 5320, caja 2, exp. 12, fol. $13 \mathrm{v}$. 
Del tercer hermano, Francesc Valleriola, sabemos que había nacido antes de 1467, fecha en que su madre otorgó un testamento no publicado en el que lo mencionaba a él y a sus otros hijos mayores ${ }^{104}$. Según las confesiones que hizo su hermano Joan Valleriola III ante el tribunal en 1531, tanto Francesc como sus otros hermanos Lluís y Gràcia ya habían fallecido en esa fecha ${ }^{105}$. Una escueta noticia incluida en un índice de procesos inquisitoriales permite pensar que, con posterioridad a 1506, Francesc había contraído matrimonio con una hija de Lluís de Na Flor; y que en torno a 1531 -cuando su hermano afirmaba que había muerto- fue sometido por el Santo Oficio, no sabemos si en persona o en ausencia, a un procedimiento de inhabilitación para el ejercicio de cargos públicos ${ }^{106}$.

Gràcia, apodada Graciosa, era la mayor de las dos hijas de Daniel Valleriola II y Brianda Belluga. Algunos documentos inquisitoriales sitúan la fecha de su nacimiento entre 1469 y 1470, pero su madre ya la mencionaba en su testamento de 1467, que tal vez otorgó en una situación de peligro resultante del alumbramiento de la propia Gràcia ${ }^{107}$. Al igual que su hermano Francesc, no aparece en los procesos inquisitoriales abiertos contra la familia antes de $1531 \mathrm{y}$, hasta donde sabemos, nunca fue encausada por la Inquisición. En alguna fecha anterior a 1493, cuando nació su primogénito Pere, Gràcia contrajo matrimonio con el mercader Joan Guimerà, hijo del sedero Bernat Guimerà. Este último, junto con su esposa Violant, estuvieron entre los primeros procesados por la nueva Inquisición en 1482, pero sería la segunda causa abierta contra ellos en 1490 la que los conduciría a la hoguera. Unos años más tarde, en 1495, fue procesado y penitenciado el marido de Gràcia, Joan Guimerà, aunque ignoramos los términos concretos de la sentencia. En 1506 el matrimonio tenía cuatro hijos varones, al mayor de los cuales

104 Cf. supra nota 94.

105 Inq. leg. 1014, caja 1, s.n., s.f.

106 Inq. leg. 5320, caja 2, exp. 10, fol. 22v. Lluís Sánchez, llamado de Na Flor, tejedor de velos, tenía en 1506 cuatro hijas, dos casadas con sendos artesanos y otras dos solteras que contaban entonces 15 y 19 años de edad. Francesc Valleriola, que en esa fecha contaba unos cuarenta años de edad, pudo haber contraído matrimonio con alguna de estas dos últimas en un momento no muy posterior; Conversos de Valencia, págs. 450-451.

107 Cf. supra nota 94. 
habían llamado Pere ${ }^{108}$. Según los índices de procesos, Joan Guimerà fue encausado de nuevo en 1523, aunque también logró sobrevivir ${ }^{109}$. En 1531, según las confesiones de Joan Valleriola III, ambos cónyuges habían fallecido.

El quinto hijo del matrimonio Valleriola-Belluga fue el mencionado Joan Valleriola III, que se dedicó al comercio. Según su propia declaración en el censo de conversos de 1506, había nacido en 1473, un dato que confirman ulteriores procesos. En 1506 estaba casado con Isabel, hija del mercader Pere Gençor, con la que tenía tres hijos, todos de corta edad, cuyos nombres desconocemos ${ }^{110}$. No parece haber sufrido ningún procedimiento inquisitorial en su propia persona hasta 1531. En 1529, sin embargo, su esposa Isabel fue encausada y quemada, un hecho que unido a los antecedentes acumulados por sus padres y hermanos, debió poner a Joan en una situación peligrosa. Finalmente fue encarcelado, interrogado y torturado para que facilitara información sobre ciertas ceremonias judaicas que habrían tenido lugar en su casa entre 30 y 45 años antes. Sentenciado finalmente a penas menores, pecuniarias o de prisión, en 1534 seguía vivo y se encontraba en libertad, aunque siempre a disposición de los inquisidores, que en esa fecha lo convocaron para que ratificara sus anteriores confesiones ${ }^{111}$.

El sexto hijo de Daniel y Brianda fue Baltasar Valleriola, que tomó la profesión de cambista quizás por influencia de su familia materna. No conocemos el año de su nacimiento, aunque en el proceso abierto contra él por la Inquisición, que se alargó entre abril de 1500 y mayo de 1502 , se le calificaba como «mancebo», de manera que por esas fechas debía contar 25 años como mucho. Estaba casado desde poco tiempo antes con Violant, hija del mercader Galceran Ferrer y de la primera esposa de este, Beatriu. Por la declaración de su padre en el

108 Conversos de Valencia, págs. 201-202 y 452-453.

109 Inq. leg. 5320, caja 2, exp. 10, fol. 38.

110 En el censo inquisitorial de 1506 fueron omitidos a menudo los nombres de los niños pequeños, Conversos de Valencia, pág. 439.

111 Inq. leg. 1014, caja 1, s.n., s.f. Su nombre aparece con fecha de 1531 en el índice general de los procesos que no sufrieron la pena capital; Isabel Gençor está, por el contrario, en la lista de relajados al brazo secular con fecha de 1529 (Inq. leg. 5320, caja 2 , exp. 10, fol. $38 \mathrm{v}$; y exp. 12 , fol. $15 \mathrm{v}$ ). 
censo de conversos de 1506, sabemos que Violant Ferrer había nacido en 1480 y que no tenía hijos, tal vez como consecuencia directa de la huida de su marido ${ }^{112}$.

Baltasar Valleriola fue uno de los primeros implicados en el caso de Miquel Vives, un sobrino de Lluís Vives II -hijo de su hermano Salvador Vives- que tras ser detenido por la Inquisición a cuenta de ciertas declaraciones imprudentes, consideró razonable alardear de haber convertido a la ley mosaica a algunos familiares y amigos. La maquinaria inquisitorial, interesada en ampliar su propia cuenta de resultados, hizo de él nada menos que un rabino oculto y de sus conciliábulos domésticos una sinagoga secreta ${ }^{113}$. Baltasar comprendió el peligro que corría y no dudó en poner tierra por medio inmediatamente; una decisión juiciosa que le salvó la vida. El 9 de julio de 1500, un notario del Santo Oficio leyó desde el púlpito de la catedral el decreto de excomunión contra Baltasar y otro fugitivo, el platero Jaume Galindo. El proceso en rebeldía abierto contra ambos terminó como era de prever. El 19 de mayo de 1502, el alguacil de la Inquisición entregó sus efigies y las de otras diez personas al alguacil del gobernador para que fueran quemadas públicamente. No parece que Baltasar volviera a ponerse nunca al alcance del tribunal; puestos a especular acerca de su destino, es probable que acabara en Nápoles, donde se había refugiado su hermano Lluís, y quizás también su padre y su hermano Gabriel ${ }^{114}$.

Leonor Valleriola era la menor de los hijos de Daniel Valleriola II y Brianda Belluga. Nació hacia 1485 y en torno a 1502 se había acordado

112 Los escribanos del tribunal apuntaron en aquella ocasión que el marido de Violant, Baltasar Valleriola, era «el que huyó por la sinoga»; y cuando su nombre volvió a salir en la declaración de su hermano Joan, dejaron constancia asimismo que era «el de la sinoga»; Conversos de Valencia, págs. 381 y 439.

113 Entre 1497 y 1499, el tribunal había intentado compensar el descenso producido durante la última década del siglo xv en el número de procesamientos, cerrando los procesos contra quienes habían huido desde el comienzo de sus actuaciones en 1482, que eran relativamente numerosos. La siguiente caída de la curva de procesamientos, iniciada en 1500, se vio frenada por el "descubrimiento" de la sinagoga de Miquel Vives, que se tradujo en un repunte de los casos en 1501 y una caída menos pronunciada en 1502 y 1503; Conversos de Valencia, págs. 34-37.

114 El proceso contra Baltasar Valleriola y Jaume Galindo se encuentra disperso en Inq. leg. 937, caja 4, s.n., s.f.; leg. 1006, caja 1 s.n., s.f.; y leg. 1182, caja 2, s.n., s.f. 
su matrimonio con cierto Marc de Gandia, aunque se casó finalmente con Fernando Bonavida, converso de orígenes ajenos a la vieja judería valenciana, procedente quizás de Murcia o de tierras alicantinas ${ }^{115}$. Leonor fue encarcelada e interrogada a finales de 1530 a cuenta de los ritos judaicos celebrados supuestamente en casa de sus padres treinta años antes, en torno a 1500 , cuando ella contaba 14 o 15 años de edad ${ }^{116}$. Un poco más tarde, en 1531, cuando ya le habían abierto proceso, su hermano Joan declaró contra ella bajo tortura, confirmando que había participado efectivamente en aquellas ceremonias domésticas. Solo conocemos algunos fragmentos de su proceso, aunque sabemos que acabó siendo reconciliada y que en 1534 se encontraba en libertad o, como mucho, bajo arresto domiciliario ${ }^{117}$.

En julio de 1531 el Santo Oficio publicó un llamamiento dirigido a los familiares, deudos y herederos de algunos difuntos a los que había decidido procesar por crímenes heréticos cometidos en vida, a fin de que

115 Apenas hemos encontrado rastro del apellido Bonavida en los papeles del tribunal de Valencia. Un Diego de Buenavida o Bonavida, calificado como tendero o apotecario de Murcia, así como su esposa Aldonça, fueron incluidos en los índices de procesos con fechas de 1520 y 1519, respectivamente (Inq. leg. 5320, caja 2, exp. 10, fols. 3 y 17). Por algunas páginas que se han conservado del proceso contra dicha Aldonça, sabemos que era natural de Xàtiva y que después de contraer matrimonio se había trasladado a Elx junto con su marido. En 1488, Aldonça se acogió a un edicto de gracia promulgado por los inquisidores del obispado de Cartagena y fue reconciliada. En 1505 volvió a confesar ante dicho tribunal porque en las anteriores declaraciones no había denunciado ciertas prácticas heréticas realizadas por sus padres y otros familiares. En 1518 fue encarcelada e interrogada en Xàtiva la madre de Aldonça, Violant Porta, lo que pudo conducir en los años inmediatamente siguientes al procesamiento de su hija y del marido de esta, que residían por entonces en Valencia (Inq. leg. 1145, caja 1, s.n., s.f.).

116 Leonor habría cumplido esos ayunos judaicos junto con su madre y su padre, aunque según otros testimonios hiciera ya tres años que Daniel Valleriola II había muerto. No parece, sin embargo, que estas minucias cronológicas merecieran demasiada atención por parte de los inquisidores ni, desde luego, que condicionaran en manera alguna sus decisiones. Tal vez tuvo más influencia, en aquella ocasión, la actitud adoptada por la propia Leonor, que en el momento de confesar plorant se agenollà als peus dels senyors inquisidors (Inq. leg. 1014, caja 1, s.n., s.f.)

117 Con fecha de 1531, su nombre fue incluido en el índice de procesados dentro de la lista general de quienes no habían sido relajados al brazo secular (Inq. leg. 5320, caja 2, exp. 10, fol. 50r). El día 8 de julio de 1534 respondió a un llamamiento del nuncio de la Inquisición para ratificar ante el tribunal las confesiones que había hecho cuatro años antes (Inq. leg. 1014, caja 1, s.n., s.f.). 
se presentaran a defender la «memoria y fama» de sus parientes. Entre los convocados estaban los descendientes de Daniel Valleriola II y Brianda Belluga. Era habitual, por razones obvias, que estas convocatorias cayeran en saco roto. Incluso cuando los inquisidores exhortaban personalmente a algún familiar para que se hiciera cargo de la defensa del fallecido, la respuesta solía ser negativa y el tribunal acababa designando un abogado de oficio ${ }^{118}$. Sin embargo, unos días después de que este requerimiento fuera publicado, se presentó ante los inquisidores el corredor Joan Guimerà, marido de Gràcia Valleriola, para asumir la defensa de sus suegros ${ }^{119}$. En los índices que conservamos no se menciona ningún procedimiento contra Daniel y Brianda en torno a esas fechas, quizás porque no llegó a concluirse. Solo en 1554, cuando había transcurrido más de medio siglo desde su muerte, encontramos en dichos índices una anotación relativa a un proceso abierto post mortem contra el «droguero» Daniel Valleriola II. En dicho apunte se vierte una escueta información que resulta para nosotros del mayor interés: el difunto, que había sido condenado entonces en memoria y fama, era abuelo de un notario de Valencia llamado Lluís Valleriola ${ }^{120}$. Esto supone que, a pesar de todos los infortunios causados por la persecución inquisitorial, el linaje no solo había conseguido asegurar su continuidad en la siguiente generación, sino preservar también una parte de su capital socioeconómico, pues es conocida la estrecha vinculación que el oficio notarial guardaba en aquella época con las clases medias urbanas.

Lluís Valleriola II, nacido en 1494, era el hijo primogénito del mercader Lluís Valleriola I, huido a Nápoles, y de su esposa Aldonça de Vera. En 1506, como hemos visto, vivía junto con su madre y su hermana

118 En diversas ocasiones los miembros de las familias Valleriola-Vives y ValleriolaBelluga se negaron a defender a sus parientes difuntos cuando fueron instados expresamente a ello por el tribunal. Así, en 1504, Esperança Valleriola, esposa de Lluís Vives II, se negó a defender la memoria y fama de su difunto hermano, Daniel Valleriola III (Inq. leg. 1014, caja 1, s.n., s.f.), y también la de su padre, Joan Valleriola II. Lo mismo hizo la nieta de este último, Damiata Valleriola, cuando fue exhortada en la misma fecha a hacerse cargo de la defensa de su abuelo (Inq. leg. 1051, caja 2, s.n., s.f.)

119 Inq. leg. 1014, caja 1, s.n., s.f.; otros restos documentales de los procesos post mortem contra el matrimonio Valleriola-Belluga se conservan en Inq. leg. 954, caja 1, s.n., s.f.; Inq. leg. 1162, caja 3, s.n., s.f.

120 Inq. leg. 5320, caja 2, exp. 12, fol. $7 \mathrm{v}$. 
en casa de un tío materno, el botiguer Lluís Amorós de Vera ${ }^{121}$. Alcanzada la mayoría de edad obtuvo la habilitación como notario y llevó a cabo una dilatada y exitosa carrera en las décadas centrales del siglo XVI ${ }^{122}$. La sombra de la Inquisición nunca dejó de seguirle. A lo largo de su vida alcanzó a diversos miembros de su familia, incluso cuando llevaban muchos años muertos. Su madre había sido encarcelada antes de que él naciera y su padre se exilió poco después. Siendo niño, sus abuelos y tíos paternos fueron procesados y algunos también huyeron. Años más tarde, cuando ya había alcanzado la edad adulta y comenzaba a labrarse un futuro, el largo brazo del tribunal alcanzó a su tío Lluís Amorós de Vera, ya difunto ${ }^{123}$; también procedió contra la memoria y fama de sus abuelos paternos, fallecidos treinta años antes, y encarceló a otros dos hermanos de su padre que aún permanecían en la ciudad, Joan y Leonor Valleriola, que aun pudiendo salvar la vida no se ahorraron la cárcel, el tormento y otras penitencias «saludables». Por último, en 1554, cuando Lluís ya se había convertido en un prestigioso profesional con largos años de experiencia, su abuelo Daniel Valleriola II fue procesado finalmente y condenado post mortem.

Transcurrido un siglo desde que aquel mercader mallorquín se había instalado en Valencia y más de cincuenta años desde su muerte, el escribano del tribunal creyó necesario dar explicaciones acerca de su identidad, pues aunque no quedaba prácticamente nadie que pudiera recordarlo, uno de sus descendientes era persona bien conocida: «Daniel Valeriola, droguero, agüelo de Luys Valeriola, notario». Ignoramos si la vida personal y profesional de Lluís Valleriola II se vio afectada de alguna manera por la que parece haber sido la última acometida de la Inquisición contra su familia, pero en todo caso las consecuencias no debieron resultar muy graves. A mediados del siglo XVI, las buenas relaciones que mantenía con algunas familias de la nobleza valenciana preludiaban el ascenso social de

121 Cf. supra notas 95 y 96.

122 Se conservan treinta registros notariales autorizados por él entre 1523 y 1569 (Archivo General y Fotográfico de la Diputación de Valencia. Fondo Duquesa de Almodóvar, Protocolos notariales, 46-75).

$123 \mathrm{Su}$ nombre aparece con fecha de 1529 en los índices de procesados, dentro de la lista de relajados al brazo secular, entre los difuntos condenados en memoria y fama (Inq. leg. 5320, caja 2, exp. 12, fol. 24). 
su propio linaje. En 1558 fue uno de los dos notarios que escrituraron los capítulos matrimoniales acordados entre Galceran de Castellví y Àngela de Montagut, herederos respectivos de los señoríos de Carlet y l'Alcúdia ${ }^{124}$. Poco después, en 1562, obtuvo por cesión del noble Lluís de Requesens, para quien trabajaba como procurador, el derecho de sepultura en la capilla de San Miguel, luego de San Pío V y San Benedicto XI, en el convento de los dominicos de Valencia ${ }^{125}$.

Lluís Valleriola II se casó, no sabemos cuándo, con Beatriu Almenara, de cuya ascendencia no tenemos noticia, aunque se trata de un apellido frecuente a principios del siglo XVI entre los numerosos conversos que poblaban la parroquia de Sant Tomàs, y por supuesto en los papeles de la Inquisición ${ }^{126}$. El matrimonio tuvo dos hijos varones, Andreu y Jeroni (n.1546). Poniendo en práctica por partida doble una estrategia común entre los notarios de la época, ambos cursaron estudios universitarios y obtuvieron el doctorado en derecho. Andreu Valleriola falleció de forma prematura en 1587 dejando un hijo menor de edad, Francesc, de cuya tutela se haría cargo su tío Jeroni Valleriola $\mathrm{I}^{127}$. Este protagonizó una

124 Vicent M. GARÉs TIMOR, «Conflictividad social y violencia de género en la nobleza valenciana del siglo XvI. El intento fracasado de unión de los señoríos de Carlet y l'Alcúdia», en Eliseo Serrano Martín, (coord.), De la tierra al cielo. Líneas recientes de investigación en Historia Moderna (Zaragoza: Institución Fernando el Católico, 2013) págs. 713-729: 717 y nota 25, y Vicent Joan VAlLés BorRÀs, De la carta de poblament a l'ocàs de l'antic règim, 1252-1800. Història de l'Alcúdia I (Alcúdia: Ajuntament de l’Alcúdia, 2002) págs. 179-180.

125 José Teixidor, Capillas y sepulturas del Real Convento de Predicadores de Valencia, vol. I (Valencia: Acción Bibliográfica Valenciana, 1949) págs. 231-232.

126 El censo inquisitorial de 1506 recogió las declaraciones de nueve cabezas de familia llamados Almenara, ocho varones y una mujer, que pertenecían a tres linajes distintos cuyos antecesores inmediatos eran el pintor y tundidor Bartomeu Almenara, el sastre Jaume Almenara y el veler Joan Almenara. Los tres habían fallecido en el momento en que fue compuesto el censo e ignoramos si procedían a su vez de un antepasado común (Conversos de Valencia, pág. 561). En los años inmediatamente posteriores a la destrucción de la Judería encontramos dos conversos llamados Almenara: el cortiner Bartomeu Almenara [Mossé Aluri o Atzoni] (Luz CoMPANY, Evolución y estrategias, pág. 177) y cierto Bernabé Almenara [Jucef Abbu] (ACCV, P 1287. Notario Joan d'Aguilar. 1392, julio 29), que podría ser el mismo platero Jucef Abbu que en 1383 comerciaba con Mallorca; José Hinojosa Montalvo, «Actividades judías en la Valencia del siglo XIV», En La España Medieval 7 (1985) págs. 1547-1565: 1559.

127 ACCV, P 11006. Notario Francesc Almenara. 1606, diciembre 2, 3 y 4. 
exitosa carrera profesional que se proyectó en el ejercicio de diversos cargos institucionales y culminó con la obtención en 1604 del privilegio de nobleza. Como expresión palmaria de su triunfo, emprendió en los últimos años del siglo XVI una reforma de dimensiones palaciegas en el conjunto de inmuebles que había reunido en la calle del Mar, en torno quizás a una antigua casa familiar heredada de sus ancestros conversos. No pudo ver concluida la obra porque fue asesinado en su propio domicilio durante la noche del 20 de octubre de 1606, un hecho terrible que conmocionó la Valencia de la época. Su hijo y heredero, el caballero Jeroni Valleriola II, fruto de su matrimonio con Felipa Carròs, se encargó de continuar los trabajos ${ }^{128}$.

Jeroni Valleriola I fue sepultado en el convento de los frailes predicadores de Valencia, en la capilla donde yacían sus padres, el notario Lluís Valleriola II y su esposa Beatriu Almenara, y también su hermano, el jurista Andreu Valleriola. Para entonces, el pasado hebreo del linaje debía estar muy difuminado en el recuerdo de sus convecinos, y tampoco los interesados debieron mostrar mucho interés en que perviviera. Desaparecida la cofradía de Sant Cristòfol como resultado de la represión inquisitorial ${ }^{129}$, el convento de Santo Domingo ofrecía una alternativa más prestigiosa $\mathrm{y}$, sobre todo, desligada de unos orígenes cuyo recuerdo no resultaba grato. En el mismo sentido obraba el cambio en la tradición onomástica familiar, con el abandono de nombres antes recurrentes como Daniel y Joan por otros menos habituales o incluso inéditos en la familia, como Andreu, Jeroni o Francesc. Por efecto de una estrategia de promoción socioprofesional de eficacia contrastada, y al precio de cancelar una parte importante de su pasado, estos "renovados" Valleriola vinieron a homologarse con una pequeña nobleza urbana cuyas pautas de comportamiento social adoptaron de manera escrupulosa en las siguientes centurias. Al cabo, resultó bastante difícil distinguir entre ellos y aquellos otros Valleriolas ennoblecidos con anterioridad, los descendientes de aquel banquero Arnau

128 Amparo Felipo ORTS, «El linaje Valeriola en la Época Moderna: De la fundación del vínculo familiar al condado de Almodóvar (ss. XVII-XIX)» [en curso de publicación]. Agradezco a la autora la amabilidad de permitirme consultar el texto original de este trabajo.

129 Hinojosa Montalvo, «Los conversos de judío valencianos», pág. 97. 
Valleriola de quienes habían tomado el apellido tras la liquidación de la Judería. No han faltado desde entonces los polígrafos y eruditos que remontan caprichosamente la prosapia del linaje hasta los gloriosos tiempos de Jaime I; ni los que se hacen eco de relatos menos grandilocuentes que, de manera rocambolesca y tampoco carente de imaginación, resultan sin embargo más próximos a la realidad ${ }^{130}$.

\section{Conclusión}

La genealogía de los tres linajes Valleriola constituye un buen ejemplo del devenir de las familias conversas acomodadas en la Valencia del siglo xv. Permite observar algunas de las estrategias que pusieron en práctica para afianzarse en las posiciones socioeconómicas alcanzadas tras la conversión e incluso mejorarlas; también para sortear, o al menos limitar, los efectos adversos derivados de la condición de minoría religiosa que heredaron de sus antepasados judíos. El primer grupo de estrategias, el que promovía el enriquecimiento y el prestigio de los individuos y las familias, fue el resultado de decisiones proactivas maduradas a partir del abanico de posibilidades que tenían a su alcance, y en poco o nada se diferenciaron de las adoptadas por sus convecinos cristianos viejos. Sin embargo, las estrategias del segundo grupo tenían un fuerte cariz defensivo y con frecuencia vinieron impuestas por la perentoria necesidad de salvar la hacienda o cuanto menos la vida, y en tales circunstancias faltaba tiempo para reflexionar sobre su alcance y consecuencias. Las conversiones que siguieron al pogromo de 1391 fueron de estas últimas, pues aunque no faltaron valoraciones de otro tipo -como sortear las tradicionales restricciones impuestas al acceso de los miembros de la comunidad judía al mercado de bienes y servicios-, estas se produjeron comúnmente tras el bautismo, cuando una vez garantizada de manera inmediata la seguridad física, los recién convertidos comprendieron que no solo habían cruzado -más o menos fingidamente-

130 Juan Luis Corbín Ferrer, La calle del Mar: sus casas y sus nombres (Valencia: Federico Doménech, 1973) págs. 139-140; el autor recoge una genealogía fantástica que convierte al notario Lluís Valleriola II en el hijo de un «esclavo hebreo» a quien el noble Gisbert Valleriola habría otorgado la libertad tras convertirlo al cristianismo. 
una «frontera religiosa», sino también «las de la sociedad y la cultura»; y que tras estas se abría todo un mundo de nuevas oportunidades ${ }^{131}$.

La notable presencia que los conversos de la antigua judería tuvieron en la vida social y económica del Siglo de Oro valenciano ha sido destacada sobradamente. También las complejidades del proceso de integración en la sociedad cristiana, cuya expresión más temprana sería el progresivo abandono de los calificativos «converso» y «neófito» en la documentación pública desde las primeras décadas del siglo Xv ${ }^{132}$. Los tres linajes Valleriola supieron aprovechar las oportunidades de enriquecimiento que les brindaba la nueva situación y poner en práctica estrategias profesionales y familiares que permitieran maximizar los beneficios derivados de su actividad económica. Enlaces matrimoniales y asociaciones mercantiles fueron a menudo de la mano, al tiempo que los azares de la reproducción biológica se mostraron favorables a la transmisión intergeneracional del capital económico e ideológico de la familia. Junto con el apellido, los hijos heredaron a lo largo de toda la centuria los bienes, los conocimientos técnicos y los vínculos institucionales de sus padres, dentro de una progresiva mejora de la riqueza y la consideración social que, a pesar de toda la animadversión que sin duda provocó entre los cristianos viejos u otros conversos menos afortunados, solo se vio truncada a partir de 1482 como consecuencia de la acometida inquisitorial.

Desde esa fecha, los comportamientos colectivos volvieron a verse dominados por el pánico. En un primer momento, los edictos de gracia promulgados por el tribunal pudieron sustentar la esperanza de una pronta e incruenta resolución del conflicto. Por el contrario, la persecución se recrudeció en los años siguientes. Las confesiones voluntarias, lejos de aplacar el celo del Santo Oficio y de sus regios promotores,

131 Según argumento y expresiones de Benzion Netanyahu, «¿Motivos o pretextos? La razón de la Inquisición», en Inquisición española y mentalidad inquisitoria: ponencias del Simposio Internacional sobre Inquisición, Nueva York, abril de 1983 (Barcelona: Ariel, 1984) págs. 23-44: 39-40; el asunto ha sido introducido en el contexto valenciano de 1391 por Castillo Sainz («De solidaritats jueves», págs. 192-194).

132 Hinojosa Montalvo, «Los conversos de judío valencianos», pág. 77; sobre los éxitos alcanzados por los conversos en la sociedad valenciana del siglo XV y los rencores que despertaron en algunos de sus conciudadanos cristianos viejos,véanse allí las págs. 85-87. 
terminaron sustentando posteriores procedimientos criminales que desembocaron en la destrucción sistemática de vidas y haciendas, poniendo a familias enteras en trance de desaparición. La única respuesta razonable parecía la huida, y aunque no se encontraba al alcance de todo el mundo, muchos de aquellos conversos acomodados que constituían el objetivo prioritario del tribunal emprendieron el camino del exilio, en solitario o junto con sus hijos y otros parientes. Sin duda, las fugas colectivas eran mucho más complicadas que las individuales, pues exigían un mayor esfuerzo de planificación y discreción, virtud bastante escasa en aquellas difíciles circunstancias ${ }^{133}$.

Entre los Valleriola se produjeron sobre todo fugas individuales y más bien precipitadas. En 1484, Daniel Valleriola III se embarcó hacia Nápoles dejando atrás a su esposa y su hija. Otro tanto hizo Lluís Valleriola I una década más tarde. Se trató en ambos casos de alejamientos preventivos que no llegaron a convertirse en fugas formales, pues el tribunal no los reclamó finalmente, como sí hizo con Gabriel y Baltasar Valleriola, que salvaron la vida porque emprendieron la huida a tiempo.

Pero exiliarse era una medida dolorosa y muchos optaron por permanecer en sus casas a pesar del evidente peligro que corrían. La mayoría lo hizo porque no contaba con los medios necesarios para irse; otros porque -por el motivo que fuera o de manera harto ilusoria- aún se creían a salvo. Sin desdeñar la protección que determinadas relaciones e influencias personales proporcionaron a un número reducido de indi-

${ }^{133}$ El caso que mayor sensación causó en su momento fue la huida de los banqueros Ró́s, llevada a cabo en los primeros días del mes de enero de 1487 de acuerdo con un plan estudiado al detalle que inclúa varias rutas de escape y el traslado al extranjero de una parte importante de los activos de la empresa; Enrique Cruselles Gómez, Fortuna y expolio de una banca medieval. La familia Roís de Valencia (1417-1487) (Valencia: Publicacions de la Universitat de València, 2019) págs. 284-309. Unos años antes, el corredor Pau Vives, cuñado de Daniel Valleriola I y uno de los primeros fugados de la nueva Inquisición, huyó a Francia junto con su hija Leonor y su nieta Francesca, según sabemos por las declaraciones de una antigua criada de la casa realizadas en 1497 (Inq. leg. 1094, caja 2, s.n., fol. 27). A partir del testimonio prestado en 1502 por Violant Belluga, hermana del cambista Joan Belluga II, podemos suponer que este huyó de Valencia con sus hijos en un momento indeterminado entre 1485, fecha en que declaró personalmente ante la Inquisición, y el momento de su muerte, que habría ocurrido con anterioridad a 1491 según las confesiones realizadas en esa fecha por su padre (Inq. leg. 941, caja 1, s.n., s.f.). 
viduos y familias particularmente cercanas a los ámbitos de decisión política, el destino de quienes se quedaron pasó a depender de las circunstancias siempre azarosas que condicionaban la actuación del tribunal. Según qué denuncia anónima llegaba hasta el secreto del Santo Oficio, qué vecina espiaba desde qué terraza, qué criada reñía con su patrona o qué pariente más o menos allegado se veía en el trance de ofrecer algún nombre para eludir el tormento, las ruedas de la maquinaria inquisitorial atrapaban en última instancia a unas víctimas u otras. En este sentido, parafraseando a Primo Levi, la diferencia entre los hundidos y los salvados resultaba ajena en buena medida a las aptitudes y destrezas particulares de quienes se habían convertido en objeto potencial de persecución.

Joan Lluís Vives y Lluís Valleriola II eran dos adolescentes de edad similar cuando fueron inscritos junto con sus familias en el censo que la Inquisición hizo de los conversos valencianos en 1506. Joan Lluís, nacido en 1493, vivía con sus padres en la calle de la Taberna del Gall, parroquia de Sant Martí. Lluís, nacido en 1494, se encontraba junto con su hermana y su madre en casa de un hermano de esta, en la parroquia de Santa Caterina, cerca de la plaza del Mercado. Por entonces, la muerte de sus abuelos paternos y la huida de su propio padre y de algunos de sus tíos, había desarticulado las estrategias de reproducción del linaje Valleriola-Belluga, que se encontraba en evidente peligro de extinción. Por comparación, y aunque seriamente amenazada, la familia Vives todavía conservaba cierta integridad. Pero a diferencia del filósofo, que a los 16 años emprendería un viaje de estudios por Europa del que nunca regresaría, Lluís Valleriola II permaneció en Valencia. Quizás su madre y su tío no contaban con los medios necesarios para enviarlo al extranjero y alejarlo del peligro, pero sí consiguieron activar una estrategia ocupacional de larga tradición entre los artesanos y comerciantes acomodados. El acceso a la profesión notarial vino en esta ocasión a asegurar la supervivencia de la estirpe.

Por supuesto, para obtener un éxito similar al que ya había disfrutado en las décadas centrales del siglo xv, esta "renovada" familia Valleriola necesitaba algo más que dinero y buenas relaciones. Sus miembros tomaron una decisión similar a la que había marcado, más de un siglo antes, el devenir de los conversos de la antigua Judería: cancelar el pa- 
sado y adoptar como propio el imaginario de la sociedad en la que, para sobrevivir, necesitaban integrarse. El notario Lluís Valleriola II utilizó su profesión y los beneficios materiales e ideológicos obtenidos de ella para proyectarse, no como sus antepasados conversos en las clases medias artesanales y mercantiles, sino en aquella pequeña nobleza que a principios del siglo XVI encarnaba en el medio urbano el comportamiento y los valores sociales superiores. Este era un camino que ya habían recorrido antes muchas familias de notarios y, como en tantos otros casos, sus esfuerzos se vieron coronados por el éxito en la generación siguiente. Como Joan Lluís Vives en su exilio, Lluís Valleriola II no llegó a desprenderse en ningún momento de la sombra de la Inquisición; pero esta, ocupada en engullir a otros, tampoco consiguió nunca darle alcance.

Recibido: $15 / 09 / 2021$

Aceptado: 03/11/2021 
